\title{
Quaternary depositional environments in the Vrgoračko Polje/ Lake (SE Croatia)
}

\author{
†Hrvoje Posilović ${ }^{1}$, Lidija Galović ${ }^{1}$, Petar Stejić ${ }^{2}$, Mihajlo Pandurov² and Rodoljub Gajić ${ }^{2}$ \\ ${ }^{1}$ Croatian Geological Survey, Sachsova 2, Zagreb, Croatia (Igalovic@hgi-cgs.hr) \\ ${ }^{2}$ Geological Survey of Serbia, Rovinjska 12, Beograd, Serbia
}

doi: $10.4154 / g c .2018 .16$

\section{Article history: \\ Manuscript received December 09, 2016 \\ Revised manuscript accepted September 06, 2018 Available online October 12,2018}

Keywords: karst polje, lacustrine facies, lake sediment, Quaternary, Vrgoračko polje, Croatia

\begin{abstract}
The Vrgoračko polje is a karst field with a surface area of $37 \mathrm{~km}^{2}$ and an altitude of between 20 and $28 \mathrm{~m}$ above sea level, situated at the southern edge of the Dalmatian Zagora. During the Quaternary the polje was flooded for variable periods of time and a lacustrine environment was established. A multidisciplinary study of drill-cores, outcrops and geoelectric measurements recognised five main sedimentary facies: laminated sediment, redeposited sediment, coarsegrained carbonate debris, littoral clay and lacustrine chalk. Based on the facies analysis, depositional environments developed during the Holocene include aquatic lacustrine littoral and deeper-water environments. The terrestrial environment is represented by a desiccated lake phase. The littoral clay facies (filling depressions and caverns in the karst relief) is laterally equivalent to the deep-water laminated facies (varves?). A stratigraphic break between littoral clay and lacustrine chalk could be time-equivalent to disturbed laminated sediments deposited in deeper-water and to local intercalations of coarse-grained carbonate debris in shallow-water facies sediments. These features could have been the result of a neotectonic event (earthquake), which triggered debris flows of colluvial material from slopes around the lake, and this could also have changed the hydrological regime of the Vrgoračko polje and affected subsequent depositional facies. According to ${ }^{14} \mathrm{C}$ dating, deposition of the lacustrine chalk started at the beginning of the Mid-Holocene Warm Period $(7686 \pm 36 \mathrm{aBP})$ with a sedimentation rate of approximately $0.51 \mathrm{~mm} \mathrm{a}^{-1}$ during the Middle, and $0.58 \mathrm{~mm} \mathrm{a}^{-1}$ during the Late Holocene to today. Calculated carbonate production was estimated at $1050 \mathrm{gm}^{-2} \mathrm{a}^{-1}$. A temporary phase of subaerial exposure of the lake is indicated by desiccation cracks and two bioturbated palaeosol horizons. The described depositional environments and sediment facies found in the Vrgoračko polje could be considered to represent a typical Quaternary lacustrine sedimentation pattern for other Dinaric karst poljes.
\end{abstract}

\section{INTRODUCTION}

Karst polje are extremely important geomorphological features not only in a cultural sense (PILAAR BIRCH \& VANDER LINDEN, 2018), but also as a geological phenomenon. Polje is the internationally accepted Slavic word for karst polje, described and classified by FORD \& WILLIAMS (2007, p.361-365). Poljes, are small to large flat areas in rough karstic terrain, are usually places of sediment accumulation, which may well be the only fertile areas for agriculture in the district (ROMIĆ et al., 2014). In many cases in the recent past, the poljes were seasonally flooded and temporary lacustrine environments were established (FORD \& WILLIAMS, 2007).

Lakes in karstic areas and their sediment accumulations can provide an exclusive record of changes in a local and global environment. An excellent example is the Vrgoračko polje with its water originating from estavelles (= reversing springs that can temporarily function as ponors) (FORD \& WILLIAMS, 2007). Ponor is another internationally accepted Slavic word for swallow hole (FORD \& WILLIAMS, 2007, p. 118). The estavelles are mostly situated along the north-western edge of the Vrgoračko polje. During the autumn, heavy seasonal rainfall, especially in the hypsometrically higher poljes of the Dalmatinska Zagora, causes activation of the estavelles, resulting in flooding of the polje. Such a seasonal fluctuation of the water level and alternation between lake and dry polje is a well-known phenomenon and described in the Cerkničko polje, Slovenian Dinaric karst (VALVASOR, 1689; PLENIČAR, 1954; SMREKAR, 2000). Similarly, in the karstic Lake Banyoles (NE Spain), MORELLÓN et al. (2014) reported intense groundwater inflow that leads to the fluidization and re-suspension of previously deposited sediments. Seasonal autumn flooding of the Vrgoračko polje may (re)establish a lacustrine environment that lasts through the winter as confirmed by zonal vegetation around the polje (Fig. 1). Likewise, seasonal runoff through estavelles and ponors into the Neretva River (E of the Vrgoračko polje), and the artificial Prigon tunnel draining into the Baćinska Lakes (S of the Vrgoračko polje), leave the Vrgoračko polje dry throughout the summer. The Matica River is the only permanent stream that meanders from its springs in the NW, splits to the south and the east and then sinks (Fig. 1). The altitude difference between the springs, estavelles and ponors is approximately 8 metres. The process of seasonal alternation of lacustrine and terrestrial environments is repeated annually.

However, historically, the Vrgoračko polje used to be flooded all year round, with seasonal water-level fluctuation (personal communication from residents). Likewise, temporary desiccation of the Vrgoračko polje could have lasted for years and centuries. In the south-eastern part of the Vrgoračko polje, a medieval cemetery is located with monumental tombstones known as stećci - a valuable cultural heritage originating from the Middle Ages ( $\mathrm{N}=43^{\circ} 06$ '53'; $\mathrm{E}=17^{\circ} 26^{\prime} 40^{\prime \prime}$ at an altitude of about $35 \mathrm{~m}$ above sea level) (TOMASOVIĆ et al., 2008). It can be assumed that the 


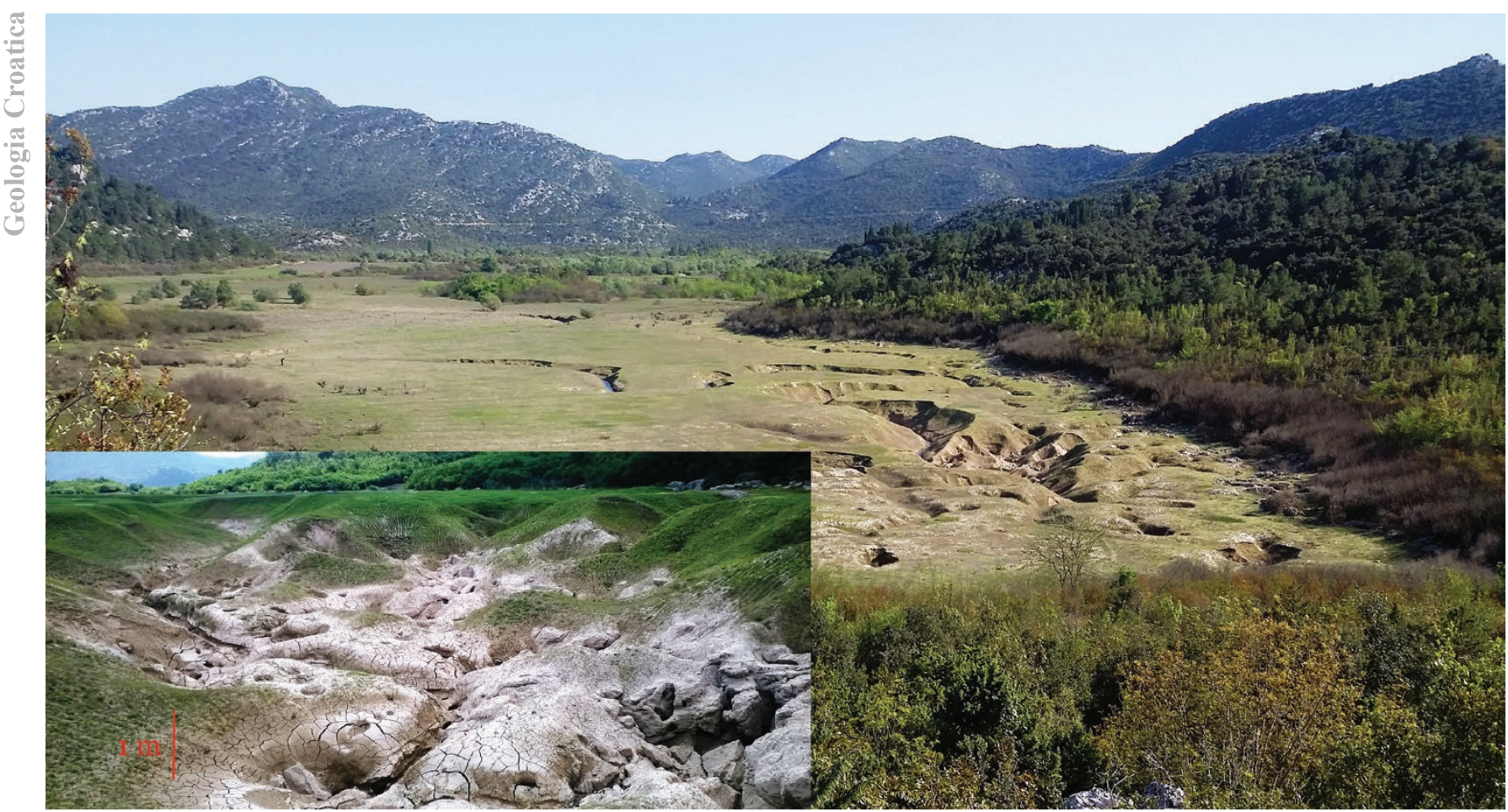

Figure 1. Panorama of the Plina area with detail of one of the branches of the Matica River and one of the estavelles (June). Inset: Erosional area around estavelles with desiccation cracks (April).

inhabitants would not have located a cemetery where there is a high chance of flooding.

The aim of this paper is to describe and interpret the lacustrine sediments of the Vrgoračko polje, with a special focus on erosion and resedimentation of the lake sediments as a consequence of water runoff. The facies and depositional environments described here provide a basis for future more detailed research and comparisons with other Quaternary lacustrine sediments from elsewhere in the Dinaric karst.

\section{GEOLOGICAL SETTING}

The investigated area is located in the Dalmatian Zagora region NE of the Biokovo Mountain in SE Croatia (Fig. 2). The orientation of the main tectonic structures is NW-SE (the Dinaric strike) (HERAK, 1986, 1991). Neotectonic movements are still active in the region (CVIJANOVIĆ et al., 1981; BOŽIČEVIĆ \& BENČEK, 1983; HERAK et al., 1995, 1996; BLAS̆KOVIĆ, 1998; DRAGIČEVIĆ et al., 1999; VLAHOVIĆ et al., 2007).

The Vrgoračko polje is located at the southern edge of the Dalmatian Zagora with an elongation along the Dinaric trend, enclosing an area of $37 \mathrm{~km}^{2}$; the elevation drops to the SE from an altitude of 28 to $20 \mathrm{~m}$ above sea level. The Vrgoračko polje is mostly formed on Upper Cretaceous limestones and to a smaller extent on Palaeocene to Eocene limestone and Eocene flysch (MARINČIĆ et al., 1972; MAGAŠ et al., 1972) (Fig. 3). Structurally, the area is developed on faults and overturned anticlinal structures with Cretaceous limestones thrust on to the Eocene flysch, so this area could be regarded as a structural polje (FORD \& WILLIAMS, 2007, p. 363-364).

In an earlier study, two main depositional units within the Vrgoračko polje were described: lacustrine chalk and Pleistocene clay (MAGAŠ et al., 1972). These terms are retained here and discussed in a later section. On the basis of the molluscan fauna and pollen analysis, the authors dated the lacustrine section as Holocene, with sedimentation beginning in the late Pleistocene.

\section{METHODS}

\subsection{Field methods}

Field investigation and sampling were carried out during the summer of 2015 and spring of 2016 and 118 sediment samples were collected from drill-cores and outcrops (Fig. 3). Specifically, samples were collected from the Plina (48) and Umčani (30) trenches, from Plina I (4) and Špila (7) outcrops and from five drill-cores $(29=6+6+4+3+10)$ (Table 1). Additionally, eight samples from drill-cores (V1 (3), V2 (1), V3 (3), V4 (1)) were collected for a study of their sedimentological and post-depositional features (micromorphological analysis).

At five locations along the NE edge of the Vrgoračko polje, five to eight metre long, $12 \mathrm{~cm}$ diameter cores were drilled. Sampling intervals were defined based on colour, composition, sedimentological characteristics and the presence of fossils. If a lithological unit was thicker than one metre, at least one sample was collected per metre.

Four sections were investigated in detail (Plina, Umčani, Plina I and Špila) (Fig. 3). After removing the uppermost $20 \mathrm{~cm}$ (modern soil), horizons were defined on the basis of colour, lithological characteristics (composition, structure and texture) and the presence of fossils. The lateral extent of horizons and contacts in vertical sections were described in order to reconstruct sedimentation-erosional processes and rates. Samples weighing about $3 \mathrm{~kg}$ were taken at $10 \mathrm{~cm}$ intervals in the Plina (Fig. 4) and the Umčani sections. In the Plina I and Špila outcrops one sample was collected for each recognized horizon. Contacts between layers were described and sampled for micromorphological analysis. Colours of the samples were determined on wet sediment by reference to the Munsell Soil Colour Charts (MUNSELL SOIL COLOR BOOK, 2013). Grain size, roundness, grading and sorting of coarse-grained sediments were visually estimated based on analysis of approximately 30 grains. 


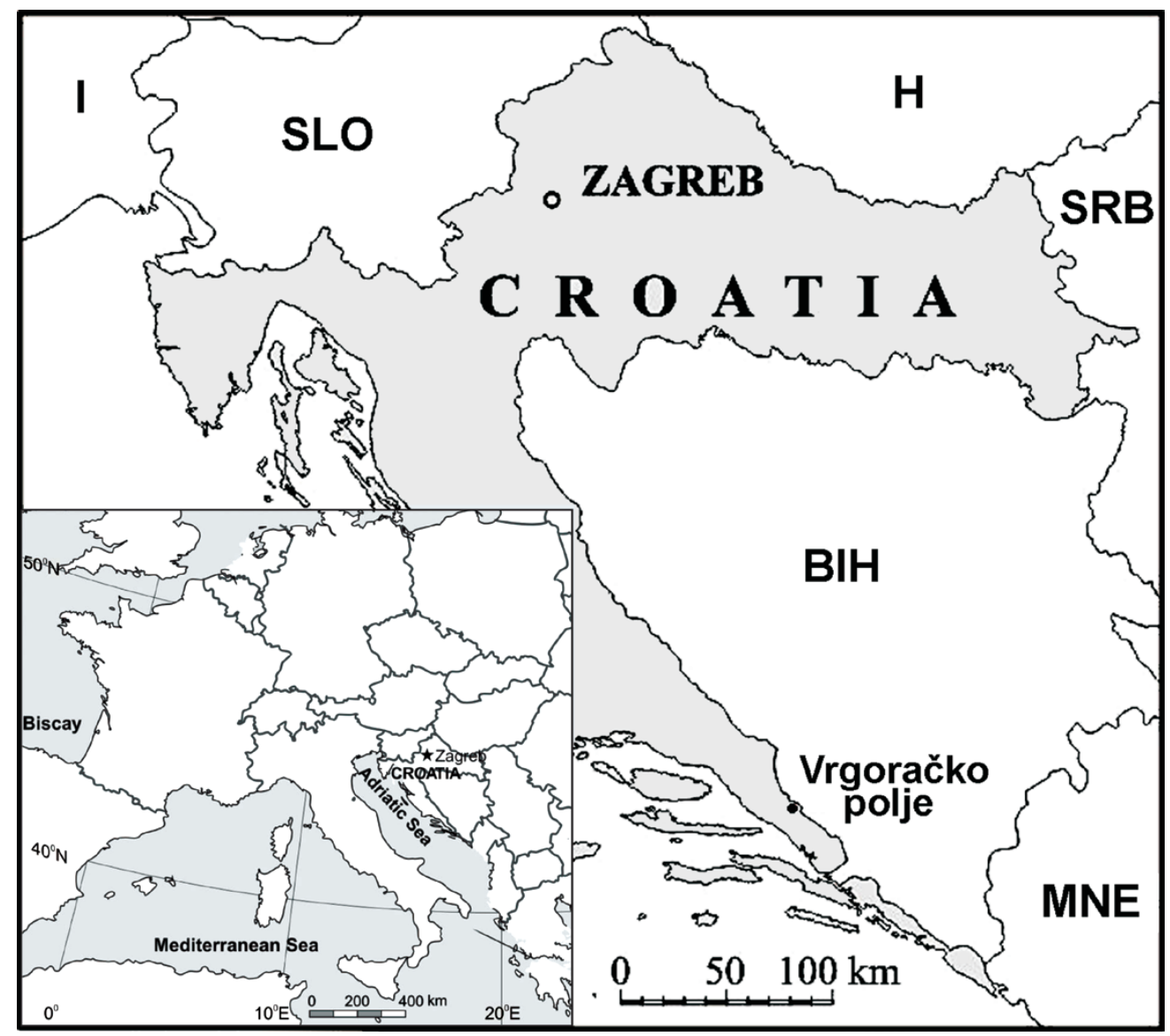

Figure 2. Location map of the Vrgoračko polje.

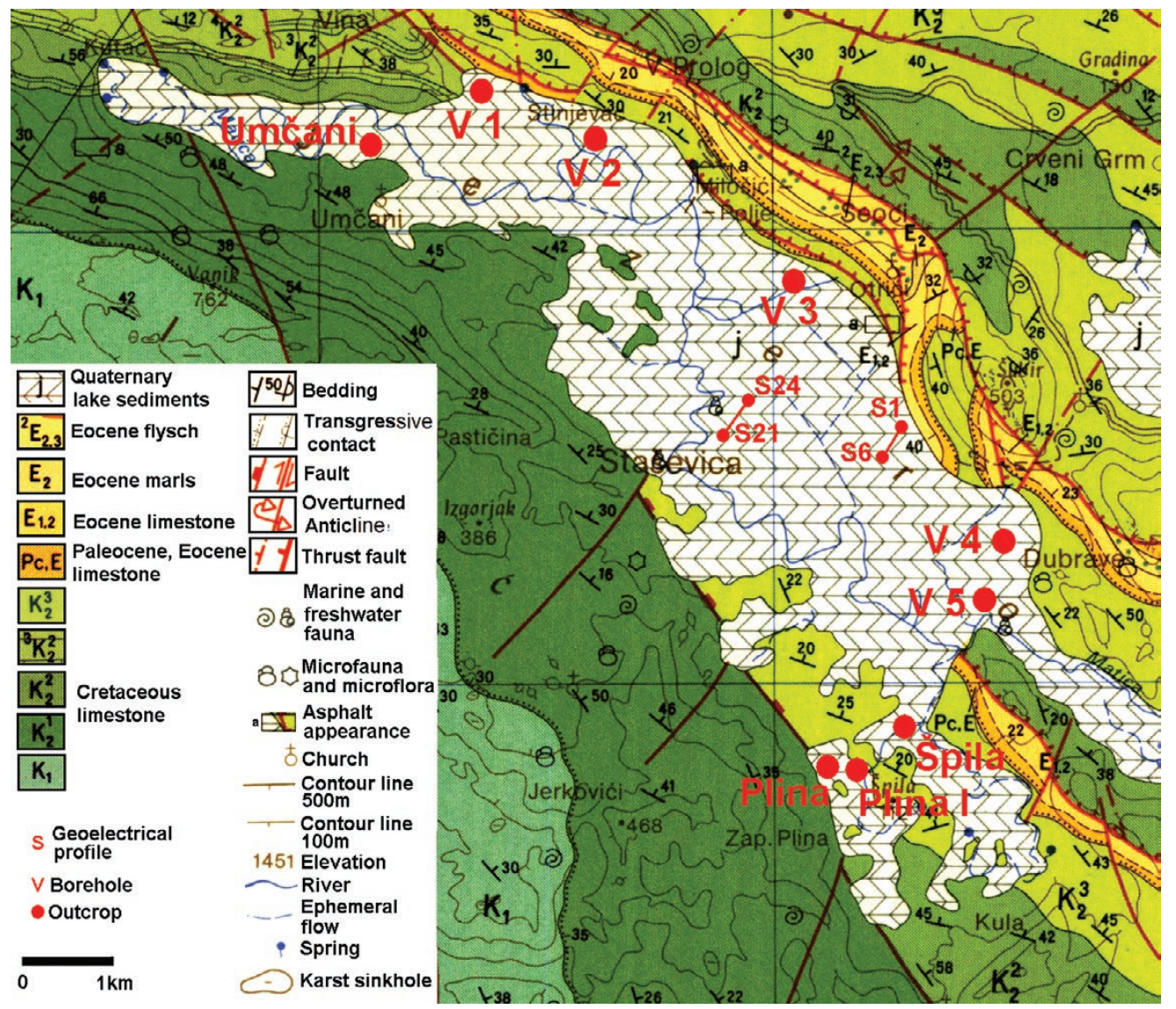

Figure 3. Geological map of the Vrgoračko polje area (MARINČIĆ et al., 1972) with the locations of investigated drill-cores (V1-V5), outcrops (Plina, Umčani, Plina I and Špila) and geoelectrical sounding profiles ( S1-S6 and S21-S24). 
Table 1. List of samples, depths of sampling and colours of analysed horizons according to the MUNSELL SOIL COLOUR BOOK (2013).

\begin{tabular}{|c|c|c|c|c|c|c|c|c|c|c|c|}
\hline \multirow{3}{*}{\multicolumn{2}{|c|}{$\begin{array}{l}\text { Sample Hight above } \\
\text { the bedrock or } \\
\text { the bottom of } \\
\text { the core }(\mathrm{m})\end{array}$}} & \multicolumn{2}{|c|}{ MUNSELL COLOUR (2013) } & \multirow{2}{*}{$\begin{array}{l}\text { Sample } \\
\text { Trench P } \\
\end{array}$} & \multicolumn{2}{|l|}{$\begin{array}{l}\text { Depth } \\
\text { from } \\
\text { bedrock } \\
\text { (m) }\end{array}$} & \multirow{2}{*}{ JLOUR (2013) } & \multirow{3}{*}{$\begin{array}{l}\text { Sample } \\
\text { Trench U } \\
\text { VU } 1\end{array}$} & \multirow{4}{*}{$\begin{array}{l}\text { Hight } \\
\text { above the } \\
\text { bedrock } \\
(\mathrm{m})\end{array}$} & \multicolumn{2}{|c|}{ MUNSELL COLOUR (2013) } \\
\hline & & & & & lina N43 & $6993^{\circ}$, E 17.3 & & & & $3.16993^{\circ}, \mathrm{E} 1$ & $.38892^{\circ}$ \\
\hline & & $412^{\circ}$ & & VJ 1 & $0.0-0.1$ & 7.5 YR 4/4 & brown & & & 7.5 YR $3 / 3$ & dark brown \\
\hline $1 / 1$ & $3.4-4.6$ & 10 YR 5/6 & yellowish brown & VJ 2 & $0.1-0.2$ & 7.5 YR 4/4 & brown & VU 2 & & 7.5 YR $3 / 3$ & dark brown \\
\hline $1 / 2$ & $3.2-3.4$ & 10 YR 5/6 & yellowish brown & VJ 3 & $0.2-0.3$ & 7.5 YR 4/4 & brown & VU 3 & $0.2-0.3$ & 7.5 YR $3 / 3$ & dark brown \\
\hline $1 / 3$ & $2.0-3.2$ & 7.5 YR 4/4 & brown & VJ 4 & $0.3-0.4$ & 7.5 YR 4/4 & brown & VU 4 & $0.3-0.4$ & 7.5 YR $3 / 3$ & dark brown \\
\hline $1 / 4$ & $1.8-2.0$ & $10 Y R 4 / 4$ & dark yellowish brown & VJ 5 & $0.4-0.5$ & 7.5 YR 4/4 & brown & VU 5 & $0.4-0.5$ & 7.5 YR $3 / 3$ & dark brown \\
\hline $1 / 5$ & $1.0-1.8$ & 10 YR 4/4 & dark yellowish brown & VJ 6 & $0.5-0.6$ & 7.5 YR 4/4 & brown & VU 6 & $0.5-0.6$ & 7.5 YR $3 / 3$ & dark brown \\
\hline $1 / 6$ & $0.0-1.0$ & $10 Y R 4 / 4$ & dark yellowish brown & VJ 7 & $0.6-0.7$ & $7.5 Y R 4 / 4$ & brown & VU 7 & $0.6-0.7$ & $7.5 Y R 3 / 3$ & dark brown \\
\hline VRG 2 & $\mathrm{~N} 43.172^{\circ}, \mathrm{E} 17.4$ & $418^{\circ}$ & & VJ 8 & $0.7-0.8$ & 7.5 YR 4/4 & brown & VU 8 & $0.7-0.8$ & 7.5 YR $3 / 3$ & dark brown \\
\hline $2 / 1 a$ & $3.80-4.80$ & 10 YR $6 / 4$ & light yellowish brown & VJ 9 & $0.8-0.9$ & $7.5 Y R 4 / 4$ & brown & VU 9 & $0.8-0.9$ & 7.5 YR $3 / 3$ & dark brown \\
\hline $2 / 1 \mathrm{~b}$ & $2.80-3.80$ & 10 YR $6 / 4$ & light yellowish brown & VJ 10 & $0.9-1.0$ & $10 Y R 5 / 4$ & yellowish brown & VU 10 & $0.9-1.0$ & 7.5 YR $3 / 3$ & dark brown \\
\hline $2 / 1 c$ & $1.80-2.80$ & 10 YR $6 / 4$ & light yellowish brown & VJ 11 & $1.0-1.1$ & $2.5 Y 7 / 3$ & pale brown & VU 11 & $1.0-1.1$ & 7.5 YR $3 / 3$ & dark brown \\
\hline $2 / 2$ & $1.50-1.80$ & $10 Y R 4 / 4$ & dark yellowish brown & VJ 12 & $1.1-1.2$ & $2.5 Y 7 / 3$ & pale brown & VU 12 & $1.1-1.2$ & 7.5 YR $3 / 4$ & dark brown \\
\hline $2 / 3$ & $1.25-1.50$ & $10 Y R 4 / 3$ & brown & VJ 13 & $1.2-1.3$ & $2.5 Y 7 / 3$ & pale brown & VU 13 & $1.2-1.3$ & 7.5 YR $3 / 4$ & dark brown \\
\hline $2 / 4$ & $0.00-1.25$ & 10 YR 4/4 & dark yellowish brown & VJ 14 & $1.3-1.4$ & $2.5 Y 7 / 3$ & pale brown & VU 14 & $1.3-1.4$ & 7.5 YR $3 / 4$ & dark brown \\
\hline VRG 31 & $\mathrm{~N} 43.158^{\circ}, \mathrm{E} 17.3$ & $389^{\circ}$ & & VJ 15 & $1.4-1.5$ & $2.5 Y 7 / 4$ & pale brown & VU 15 & $1.4-1.5$ & 7.5 YR $3 / 4$ & dark brown \\
\hline $3 / 1$ & $2.20-4.80$ & 10 YR $6 / 3$ & pale brown & VJ 16 & $1.5-1.6$ & $2.5 Y 7 / 4$ & pale brown & VU 16 & $1.5-1.6$ & 7.5 YR $3 / 4$ & dark brown \\
\hline $3 / 2$ & $1.65-2.20$ & 10 YR 4/4 & dark yellowish brown & VJ 17 & $1.6-1.7$ & $2.5 Y 7 / 4$ & pale brown & VU 17 & $1.6-1.7$ & 7.5 YR $3 / 4$ & dark brown \\
\hline $3 / 3$ & $1.20-1.65$ & 10 YR $4 / 4$ & dark yellowish brown & VJ 18 & $1.7-1.8$ & $2.5 Y 7 / 4$ & pale brown & VU 18 & $1.7-1.8$ & 7.5 YR $3 / 4$ & dark brown \\
\hline $3 / 4$ & $0.00-1.20$ & 7.5 YR 4/4 & brown & VJ 19 & $1.8-1.9$ & $2.5 Y 6 / 4$ & light yellowish brown & VU 19 & $1.8-1.9$ & 7.5 YR 4/4 & brown \\
\hline VRG 4 & $\mathrm{~N} 43.132^{\circ}, \mathrm{E} 17.4$ & $447^{\circ}$ & & VJ 20 & $1.9-2.0$ & $2.5 Y 6 / 4$ & light yellowish brown & VU 20 & $1.9-2.0$ & 7.5 YR 4/4 & brown \\
\hline $4 / 1$ & $2.20-5.70$ & $2.5 Y 7 / 3$ & pale brown & VJ 21 & $2.0-2.1$ & $2.5 Y 6 / 4$ & light yellowish brown & VU 21 & $2.0-2.1$ & 7.5 YR 5/4 & brown \\
\hline $4 / 2$ & $1.15-2.20$ & 10 YR 5/4 & yellowish brown & VJ 22 & $2.1-2.2$ & $2.5 Y 6 / 4$ & light yellowish brown & VU 22 & $2.1-2.2$ & 10 YR 5/4 & yellowish brown \\
\hline $4 / 3$ & $0.00-1.15$ & 7.5 YR 4/4 & brown & VJ 23 & $2.2-2.3$ & $2.5 Y 6 / 3$ & light yellowish brown & VU 23 & $2.2-2.3$ & 10 YR 5/4 & yellowish brown \\
\hline VRG 5 & $\mathrm{~N} 43.125^{\circ}, \mathrm{E} 17.4$ & $473^{\circ}$ & & VJ 24 & $2.3-2.4$ & $2.5 Y 7 / 3$ & pale brown & VU 24 & $2.3-2.4$ & 10 YR 5/4 & yellowish brown \\
\hline $5 / 1 a$ & $7.0-7.8$ & 10 YR $6 / 4$ & light yellowish brown & VJ 25 & $2.4-2.5$ & $2.5 Y 7 / 3$ & pale brown & VU 25 & $2.4-2.5$ & 10 YR 5/4 & yellowish brown \\
\hline $5 / 1 b$ & $6.0-7.0$ & 10 YR 6/4 & light yellowish brown & VJ 26 & $2.5-2.6$ & $2.5 Y 7 / 3$ & pale brown & VU 26 & $2.5-2.6$ & 10 YR 5/4 & yellowish brown \\
\hline $5 / 1 c$ & $5.0-6.0$ & 10 YR $6 / 4$ & light yellowish brown & VJ 27 & $2.6-2.7$ & $2.5 Y 7 / 4$ & pale brown & VU 27 & $2.6-2.7$ & 10 YR 5/4 & yellowish brown \\
\hline $5 / 1 d$ & $4.0-5.0$ & 10 YR $6 / 4$ & light yellowish brown & VJ 28 & $2.7-2.8$ & $2.5 Y 6 / 4$ & light yellowish brown & VU 28 & $2.7-2.8$ & 10 YR 5/4 & yellowish brown \\
\hline $5 / 1 e$ & $3.0-4.0$ & $10 Y R 7 / 4$ & very pale brown & VJ 29 & $2.8-2.9$ & $2.5 Y 6 / 3$ & light yellowish brown & VU 29 & $2.8-2.9$ & 10 YR 5/4 & yellowish brown \\
\hline $5 / 1 f$ & $2.0-3.0$ & 10 YR $7 / 4$ & very pale brown & VJ 30 & $2.9-3.0$ & $2.5 Y 6 / 2$ & light brownish gray & VU 30 & $2.9-3.0$ & 10 YR 5/3 & brown \\
\hline $5 / 1 \mathrm{~g}$ & $1.5-2.0$ & $10 Y R 7 / 4$ & very pale brown & VJ 31 & $3.0-3.1$ & $2.5 Y 6 / 2$ & light brownish gray & & & & \\
\hline $5 / 1 \mathrm{~h}$ & $1.0-1.5$ & $10 Y R 7 / 4$ & very pale brown & VJ 32 & $3.1-3.2$ & 2.5 Y $6 / 2$ & light brownish gray & & & & \\
\hline $5 / 1 i$ & $0.2-1.0$ & $10 Y R 7 / 4$ & very pale brown & VJ 33 & $3.2-3.3$ & $2.5 Y 6 / 2$ & light brownish gray & & & & \\
\hline $5 / 2$ & $0.0-0.2$ & 10 YR 4/6 & dark yellowish brown & VJ 34 & $3.3-3.4$ & $2.5 Y 7 / 2$ & light gray & & & & \\
\hline & & & & VJ 35 & $3.4-3.5$ & $2.5 Y 7 / 2$ & light gray & & & & \\
\hline Outcrop & p Plina I N 43.11 & $10^{\circ}, \mathrm{E} 17.455^{\circ}$ & & VJ 36 & $3.5-3.6$ & $2.5 Y 7 / 2$ & light gray & & & & \\
\hline VK 1 & $1.25-1.50$ & $10 \mathrm{YR} 4 / 3$ & brown & VJ 37 & $3.6-3.7$ & $2.5 Y 7 / 2$ & light gray & & & & \\
\hline VK 2 & $1.05-1.25$ & $2.5 Y 7 / 2$ & light gray & VJ 38 & $3.7-3.8$ & $2.5 Y 7 / 2$ & light gray & & & & \\
\hline VK 3 & $0.65-1.05$ & $2.5 Y 7 / 2$ & light gray & VJ 39 & $3.8-3.9$ & $2.5 Y 7 / 2$ & light gray & & & & \\
\hline VK 4 & $0.00-0.65$ & $2.5 Y 7 / 2$ & light gray & VJ 40 & $3.9-4.0$ & $2.5 Y 7 / 2$ & light gray & & & & \\
\hline & & & & VJ 41 & $4.0-4.1$ & $2.5 Y 7 / 2$ & light gray & & & & \\
\hline Outcrop & p Špila N 43.112 & $255^{\circ}$, E 17.46 & $20^{\circ}$ & VJ 42 & $4.1-4.2$ & $2.5 Y 6 / 2$ & light brownish gray & & & & \\
\hline VRG 2 & $2.1-3.7$ & $2.5 Y 7 / 3$ & pale brown & VJ 43 & $4.2-4.3$ & $2.5 Y 6 / 2$ & light brownish gray & & & & \\
\hline VRG 3 & $1.8-2.1$ & 10 YR 6/6 & brownish yellow & VJ 44 & $4.3-4.4$ & 10 YR $6 / 2$ & light brownish gray & & & & \\
\hline VRG 4 & $1.4-1.8$ & $10 Y R 4 / 4$ & dark yellowish brown & VJ 45 & $4.4-4.5$ & 10 YR $5 / 3$ & brown & & & & \\
\hline VRG 6 & $0.9-1.4$ & 7.5 YR 4/4 & brown & VJ 46 & $4.5-4.6$ & 10 YR 5/3 & brown & & & & \\
\hline VRG 7 & $0.4-0.9$ & 5 YR 4/4 & reddish brown & VJ 47 & $4.6-4.7$ & 10 YR 5/3 & brown & & & & \\
\hline VRG 8 & $0.0-0.4$ & $10 \mathrm{YR} 7 / 3$ & very pale brown & VJ 48 & $4.7-4.8$ & $10 Y R 4 / 3$ & brown & & & & \\
\hline
\end{tabular}

\subsection{Laboratory methods}

Complete preparation of samples and their analysis were undertaken in the Croatian Geological Survey, except for ${ }^{14} \mathrm{C}$ dating performed by the Radiocarbon dating service DirectAMS, USA. Samples from outcrops (89) and drill-cores (29) were air-dried for approximately one month in order to preserve micromorphological features. After drying, 8 intervals of core were selected for micromorphological observations.

\subsubsection{Micromorphological observations}

Studies of polished samples focused on the transitional layer between clay, silt and lacustrine chalk in order to determine composition, soft-sediment deformation (SSD), a source of the sediment and depositional mechanism. To avoid disturbance by drilling, the inner parts of the cores were selected for micromorphological observations. For that purpose dry core was meridionally sawn and the inner flat side was polished, lacquered and scanned. 


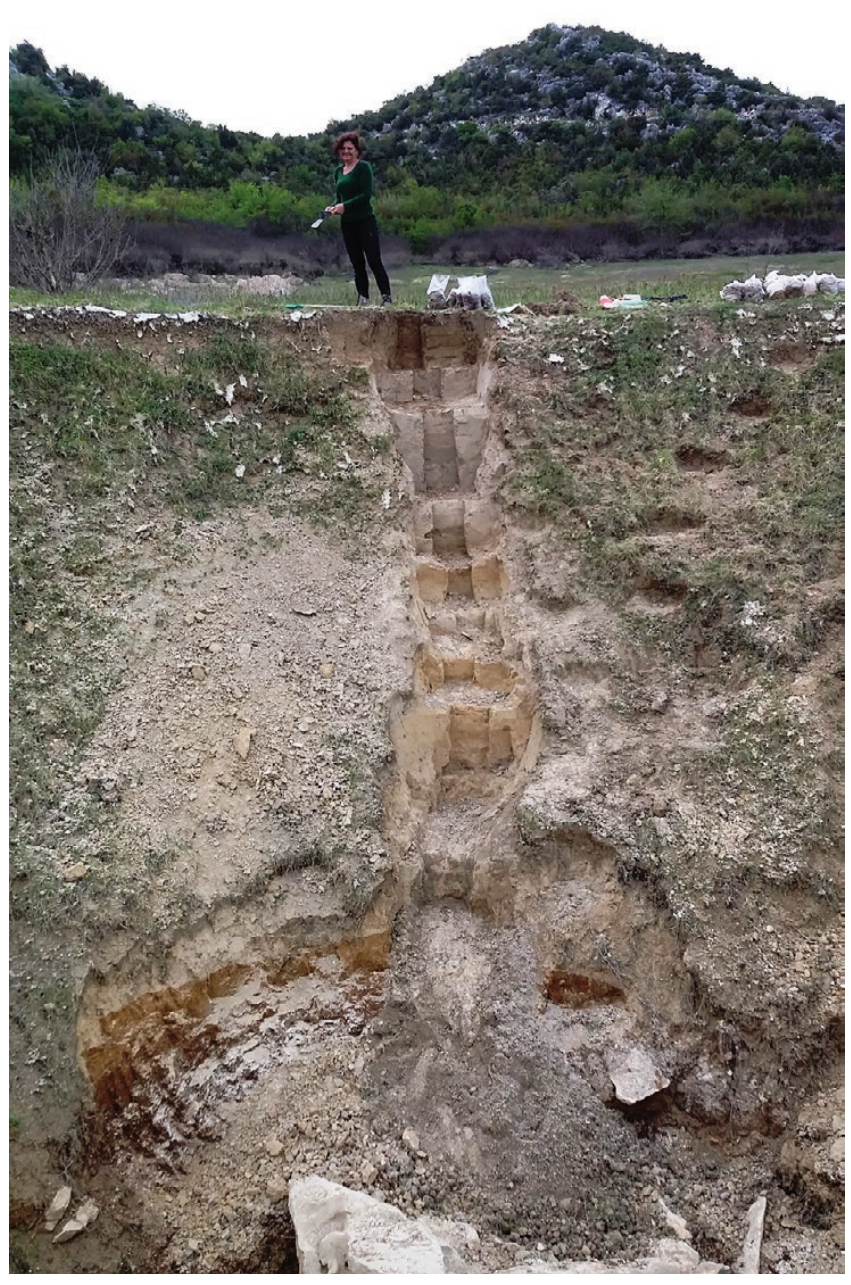

Figure 4. Trench of the Plina section.

\subsubsection{Composition of the lacustrine chalk}

The content of siliciclastic detritus was calculated after dissolving the carbonate from $0.5 \mathrm{~kg}$ of dry sediment $(5 \% \mathrm{HCl})$.

After micromorphological observation of the lacustrine chalk and visual estimation of the percentage of bioclastic material, $1 \mathrm{~kg}$ of dry sediment was soaked in water, sieved $(2 \mathrm{~mm}, 1$ $\mathrm{mm}, 0.466 \mathrm{~mm}, 0.263 \mathrm{~mm})$ and all fractions were dried $\left(105^{\circ} \mathrm{C}\right)$. Fossils larger than $2 \mathrm{~mm}$ were separated by naked-eye observation, and smaller fractions were analysed under a microscope. The diversity of bioclastic material is reported as $\mathrm{wt} \%$.

\subsubsection{Radiocarbon dating $\left({ }^{14} \mathrm{C}\right)$}

The age of the sediments was determined by radiocarbon dating (AMS method) of gastropod opercula. Bithynia tentaculata opercula are composed of calcite and were well preserved in the lacustrine chalk without any sign of recrystallization. Three samples of opercula were separated from the bottom, middle and top of the lacustrine chalk from the Plina section (samples VJ 10, VJ 15 and VJ 41) (Figs. 4 \& 6). The opercula from the clay underlying the lacustrine chalk were recrystallized and considered unsuitable for dating. The ages are expressed in years before present (aBP) where "present" is defined as AD 1950 (CURRIE, 2004).

\subsubsection{Geophysical survey}

A geophysical survey was carried out by specific electrical resistivity - geoelectric sounding. It was performed using the Schlumberger symmetrical array of current and potential electrodes with an electric range $A B / 2$ up to $200 \mathrm{~m}$. Measurements were made using a transistor compensation instrument (TK-24) on profiles in the central part of the Vrgoračko polje (Fig. 3). Quantitative interpretation of field measured diagrams of geoelectric sounding was based on a determination of the value of the electrical resistivity and thickness of the registered geoelectric units. Interpretation of measured diagrams of the geoelectric sounding album was performed using a two- and three-layer theoretical diagram. The parameters determined by the method of geoelectric sounding were: the specific electrical resistance $(\rho)$, thickness (h) and depth (d) for each geophysical unit.

\section{RESULTS}

\subsection{Description of the analysed drill-cores and sections}

The coordinates and results of the analyses of samples from the drill-cores and four sections are shown in Table 1 and Figures 5 and 6 . The sedimentological characteristics are based on visual inspection in the field.

\subsubsection{Laminated sediments}

Laminated sediments occur in the lower parts of drill-cores V1V5 located along the NE edge of the Vrgoračko polje. They are composed of alternating sub-millimetre clayey dark (7.5 YR 4/4brown (MUNSELL SOIL COLOR BOOK, 2013)) coloured and light (10 YR 6/4-light yellowish brown (MUNSELL SOIL COLOR BOOK, 2013)) coloured laminae (Fig. 5). Light coloured laminae contain yellowish to brownish and black iron and manganese oxide impregnations and micro-concretions. In some light laminae with millimetre and sub-millimetre limestone fragments and gastropod opercula (Bithynia tentaculata), the regularity and rhythmicity of lamination are disturbed and deformed. There is no visible preserved plant material. Compositional colour is determined as dark yellowish brown and brown (Table 1). The base of the laminated layer was not reached. Thus the total thickness of laminated sediments is not known and, therefore, a laminae count would have been pointless. The lamination is disturbed by SSD (Fig. 7a) in all samples, and additional disturbance by drilling was avoided in the analysed samples. Graded bedding within laminae and erosional boundaries within laminated sediments were not recognized. Based on field observations, it is the fine sediment, homogenous in appearance, except for up to 5\% siltand sand-sized limestone fragments, gastropod opercula and early diagenetic impregnations and micro-concretions (Fig. 7a). There is a sharp irregular contact of the laminated sediments with overlying disturbed clayey and carbonate sediment. Some waterescape structures could be related to cracks in the sample, and brownish to black iron and manganese oxide impregnations have been precipitated in some of them (e.g. Fig. 7a).

\subsubsection{Disturbed clayey and carbonate sediments}

These sediments were found in drill-cores V1-V5 (Figs. 3 \& 5) above the laminated sediments. They are composed of carbonate intercalations in clay sediment and clay intercalations in lacustrine chalk (Fig. 7). Alternations between these two types of deposit are marked by erosional borders (Fig. 7 (e)). In this colourful section, lacustrine chalk is light yellowish brown or yellowish brown (10 YR 6/4-5/4), and the colour of the clay ranges from brown (7.5 YR 4/4 and 10 YR 4/3) to dark yellowish brown (10 YR 4/4) (MUNSELL SOIL COLOR BOOK, 2013) (Table 1).

Numerous sub-angular limestone fragments, up to $2 \mathrm{~cm}$ in diameter are present, mostly with a corroded surface impreg- 


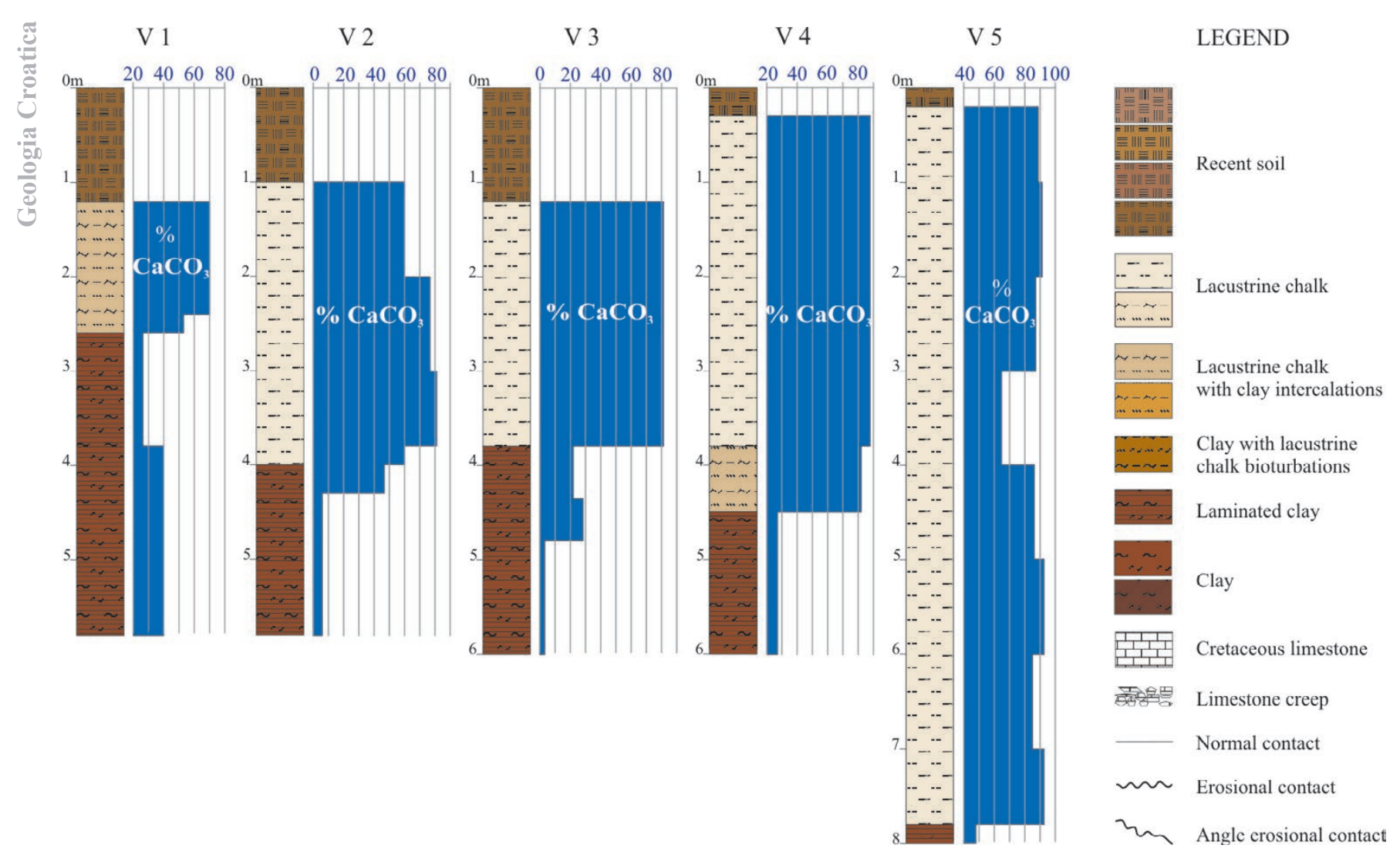

Figure 5. Lithology and carbonate content of boreholes V1-V5. For the location of boreholes see Figure 2.

nated by surrounding clay sediments, giving them an orange margin. However, the interior of all carbonate clasts is greyish and contains dense black spots of Fe-Mn oxides (Fig. $7 \mathrm{~b}$ (f)). The matrix is clay with abundant Fe- and/or Mn-nodules 3-5 mm in diameter.

Clayey clasts are composed of laminated sediment (see section 4.1.1.) within a chalk matrix. They are rounded and plastically deformed with preserved laminae (Fig. $7 \mathrm{~b}(\mathbf{c})$ ). Lamination inside the clasts is curved and folded, following the clast outlines. Gastropod opercula (Bithynia tentaculata) occur in the clayey clasts and in the silty matrix. They are well preserved, two to six $\mathrm{mm}$ long, and are imbricated following sedimentary sorting (BOGGS, 2013). Silty lacustrine chalk contains Fe- and/or Mnnodules similar to those in the clayey matrix, but they are approximately 10 times less common (Fig. 7b).

\subsubsection{Coarse-grained sediments}

Coarse-grained sediments occur in the south-eastern marginal area of the Vrgoračko polje and are described in the Špila profile (Figs. $3 \&$ 6). In view of the disturbed nature of these sediments, it was not possible to estimate their lateral extent and geometry.

Colour varies significantly (dark yellowish, yellowish, reddish brown and brown), depending on the red clay content in the matrix (Table 1). Clasts are fragments of Cretaceous limestone.

Four sediment types are present:

Very poorly sorted, clast-supported breccia with angular fragments. Cretaceous limestone clasts range in size from 5 to $70 \mathrm{~mm}$, and the matrix is a fine-grained, light-coloured carbonate with high porosity. The matrix is composed of friable skeletal debris and thus determined as lacustrine chalk. The bed thickness is ap- proximately $70 \mathrm{~cm}$, and laterally it passes into a breccia-conglomerate, retaining the same thickness.

Breccia-conglomerate, clast-supported with poor to moderate sorting of clasts. In some cases, inverse grading is followed by normal grading. Roundness of clasts ranges from angular to sub-rounded and size ranges from $5-60 \mathrm{~mm}$. Interstices between Cretaceous limestone fragments are filled with lacustrine chalk, and terrestrial gastropod shells are also present.

Clast-supported well-sorted conglomerate was observed in several loose blocks (dimensions approximately 2 x 1 x $1.5 \mathrm{~m}$ ). Two or three beds of conglomerate were recognized in each block, and they are $10-40 \mathrm{~cm}$ thick. Clasts are 5 to $50 \mathrm{~mm}$ in size and well-rounded. Cretaceous limestone clasts are imbricated parallel to the bedding plane (approximately E-W). Sorting increases with the clast roundness.

Matrix-supported, unsorted, angular to sub-angular pebbles, cobbles and boulders are intercalated in clay or lacustrine chalk (Fig. 6). The long axes of the clasts are inclined to the bedding plane. This sediment body has a channel form that is only partially preserved. The channel form in the outcrop is about $20 \mathrm{~m}$ wide and $1.5 \mathrm{~m}$ thick, and is incised into the underlying clay with a strong erosional boundary (Fig. 6). The clasts are AB-plane imbricated, where the intermediate clast axes are oriented in the flow direction and the longest axes are perpendicular to the flow to the SE (approximately 300/20).

\subsubsection{Clay}

Clay found in the lowest parts of the Plina, Umčani and Špila profiles (Fig. 6), overlies Cretaceous limestone, filling depressions and caverns in the karst relief, outcropping in ravines in the northern, western and southern sides of the polje. In the eastern part 


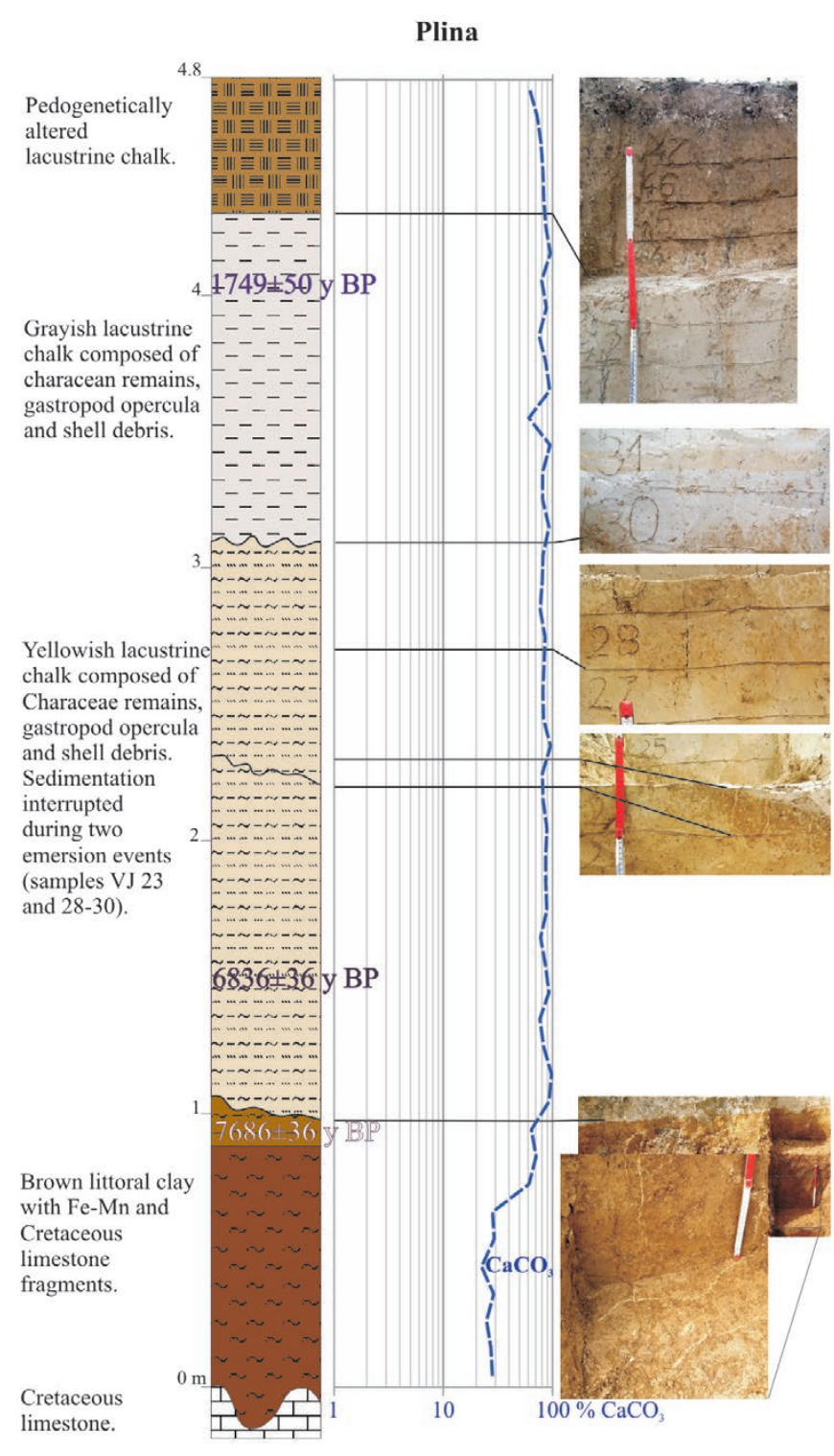

Plina I

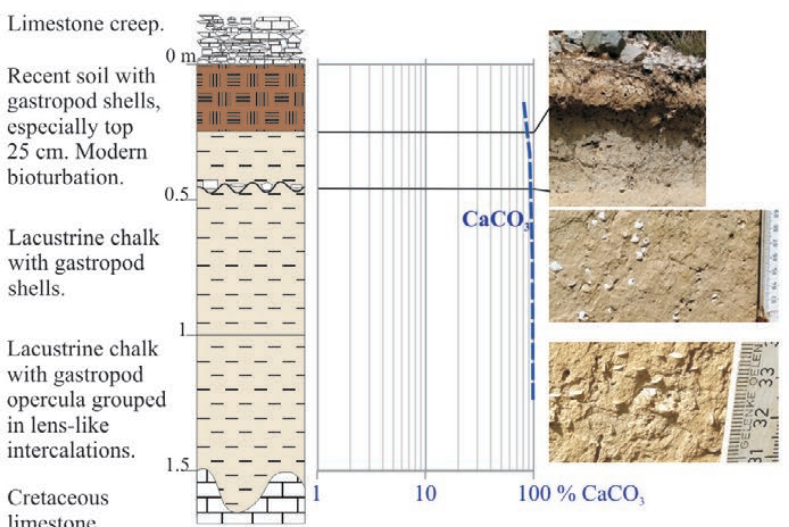

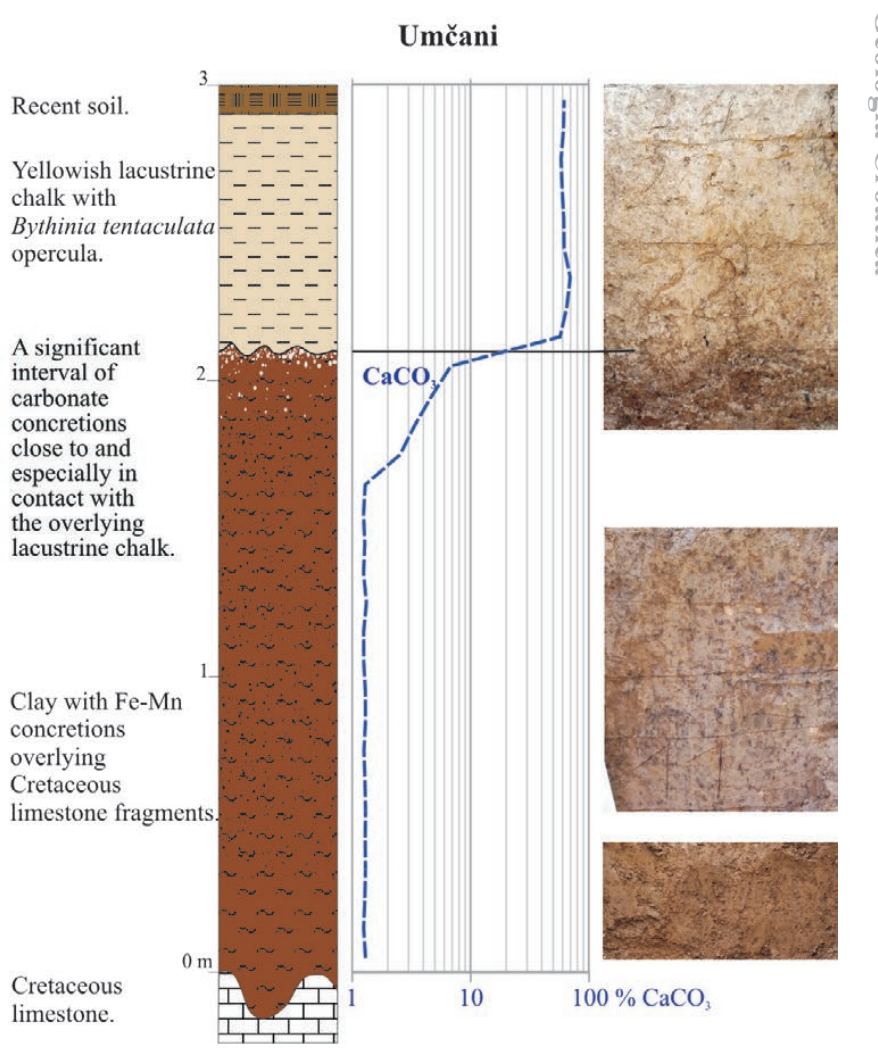
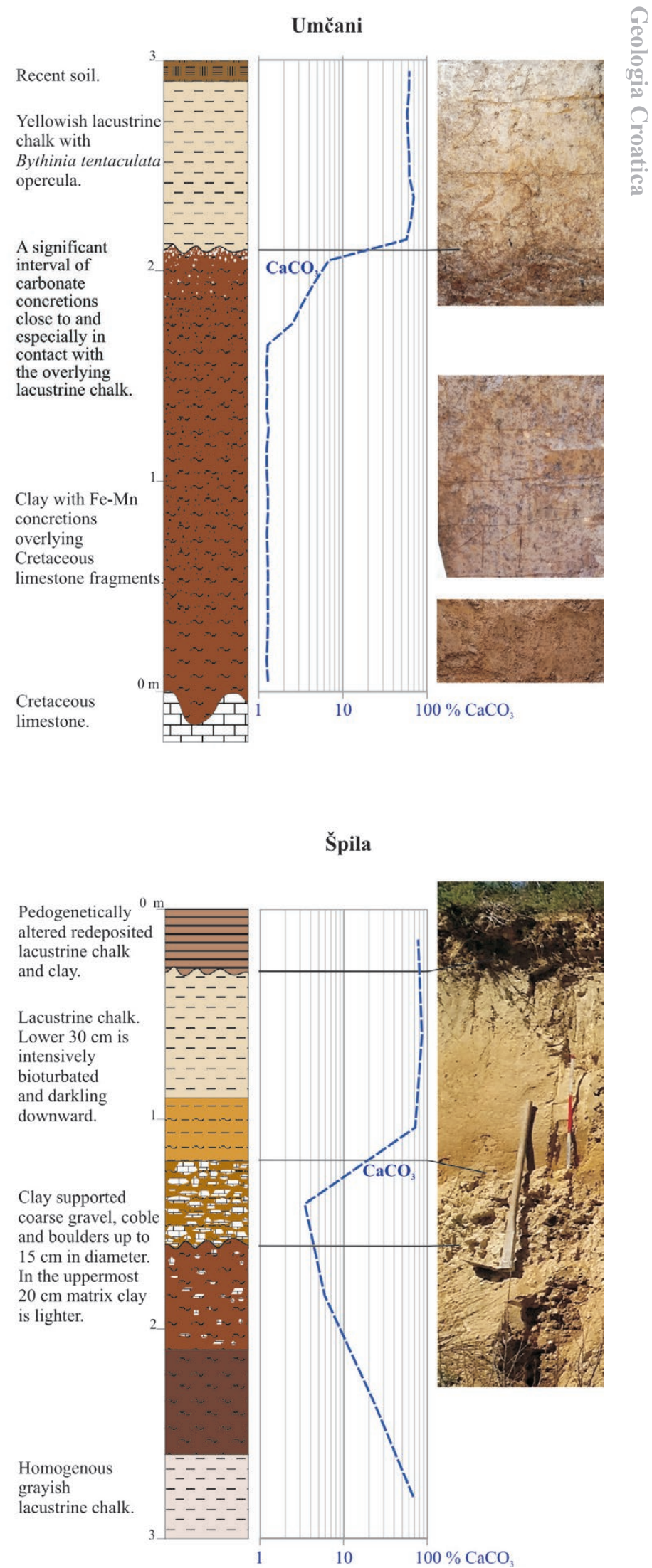

Figure 6. Lithology, age, and carbonate content of sections Plina, Umčani, Plina I and Špila illustrated by photographs of interesting details. The legend is the same as for Figure 4. For the location of the sections see Figure 2.

of the polje the clay was recognized in drill-cores as sediment that overlies the deep-water laminated or the disturbed sediments (Fig. 5). The clay was studied in the sections, because it was more reliable than investigation of its sedimentological characteristics in drill-cores. The clays are structureless and intensively bioturbated, containing numerous opercula of Bithynia tentaculata and fragments of Cretaceous limestone (Fig. 7b). In some horizons, especially the lower part of the Umčani section (Fig. 6), numer- 


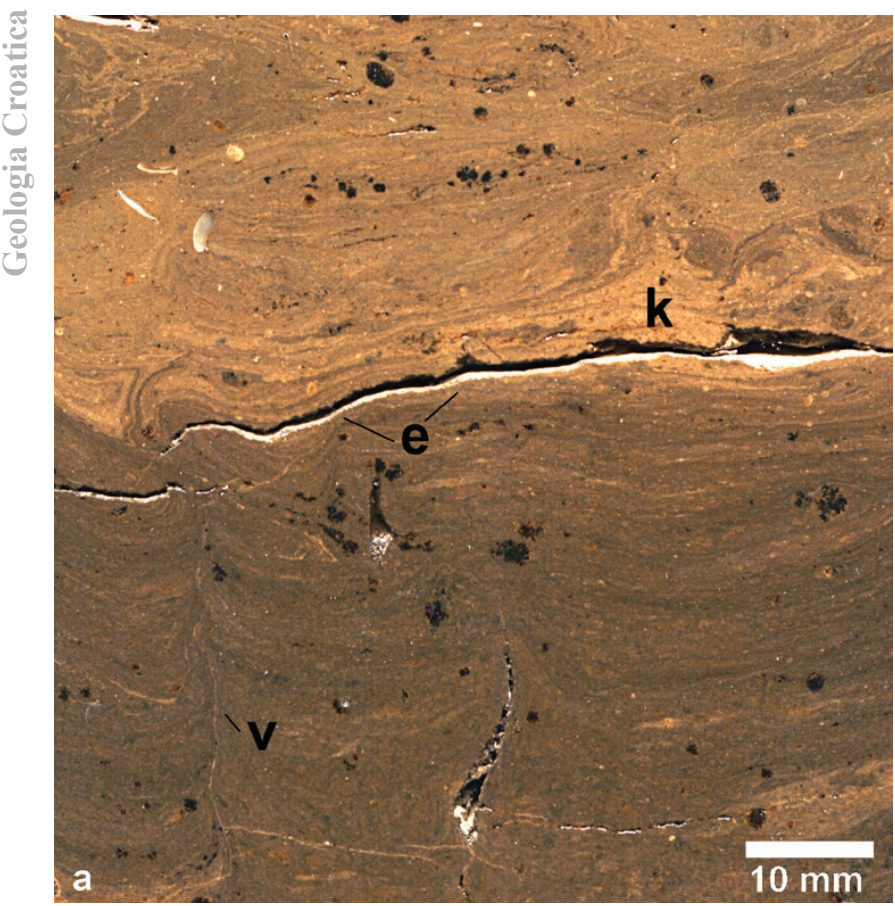

Figure 7.

a) Irregular contact of the laminated sediments (lower part of the photo) and disturbed clayey and carbonate sediments (upper part of the photo). b) The erosional boundary between sediments redeposited in a deeper lacustrine facies and littoral clays (e), Cretaceous limestone fragments that originate from surrounding slopes within littoral clays ( $\mathrm{f}$ ), the convolution of lamina (c), waterescape structure $(v)$, the redeposited material of lacustrine chalk (k).

ous iron and manganese concretions occur. Limestone fragments (if present) are mainly corroded and recrystallized, with iron and manganese oxides precipitated on their surface. In the case of recrystallized limestone fragments, Fe and $\mathrm{Mn}$ oxides are also found inside the fragments, filling and coating pores and fissures.

There is a sharp transition between the clay and the lacustrine chalk with increasing carbonate content (Fig. 4). The boundary is intensively bioturbated and burrows are filled with overlying lacustrine chalk and vice versa (Fig. 6). Likewise, the overlying sediment fills polygonal desiccation cracks in the clay (Figs. 6 \& 8).

\subsubsection{Lacustrine chalk}

Considering superposition, the lacustrine chalk is the youngest and the most widespread sediment in the Vrgoračko polje (Fig. 3 ). It occurs in all the upper parts of sections and investigated drill-cores. The chalk overlies the Cretaceous limestone in the Plina I section; the clay in the Plina and Umčani sections; coarsegrained matrix-supported clasts in the Špila section (Fig. 6); and disturbed clayey and carbonate sediments such as those found in drill-cores V1-V5 (Fig. 5). At the Plina and Umčani sections, the chalk has been deposited on top of the clay with an erosional and angular unconformity (Figs. 3, 4 \& 6). The chalk is composed almost completely of characean remains, i.e. characean thalli (tubes up to $3 \mathrm{~mm}$ in length) (Fig. 9). Biogenic carbonate material represents up to $97 \%$ of the sediment (Fig. 6), and is composed of approximately $80 \%$ of authigenic characean carbonate; $15 \%$ gastropod opercula, gastropod and ostracod debris, and the remainder comprises the siliciclastic clay fraction. Rarely, characean gyrogonites can be found, up to $30 \mathrm{psc}^{\mathrm{kg}} \mathrm{kg}^{-1}$ of the sample (Fig. 9b).

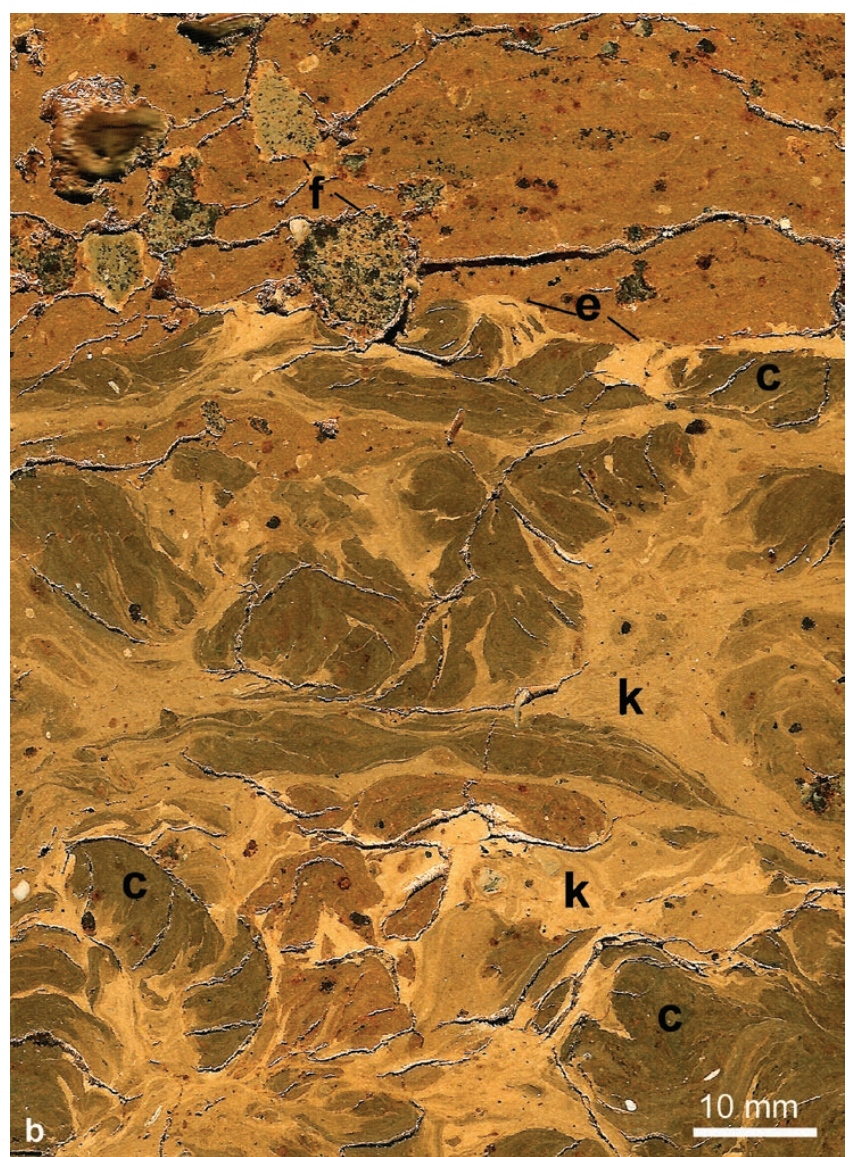

A high number of Bithynia tentaculata opercula found in littoral clays indicates a high population density.

There is no mineral or sediment filling the characean tubes, but calcite overgrowths are rarely developed on some tubes. Thalli calcification is very porous (Fig. 9a). Despite the porosity, there is no visible dissolution or corrosion of carbonate grains. The sediment colour varies from yellowish brown to light grey, depending on the clay and iron content (Table 1).

\subsection{Radiocarbon dating}

Results are presented in units of percent modern carbon (pMC) and the uncalibrated radiocarbon age before present (BP). All results have been corrected for isotopic fractionation with an unreported $\delta^{13} \mathrm{C}$ value measured on the prepared carbon by the accelerator. A beam of $\mathrm{C}$ - ions was produced by bombarding the surface of a graphite sample with $\mathrm{Cs}+$ ions. The $\mathrm{C}$ - beam was accelerated, focused and split into 14, 13 and 12 amu beams. Raw isotope ratios were transferred to proprietary data analysis software, where final calculations were performed. An aggregate carbon ratio and calculated radiocarbon age are reported and no further correction for fractionation is required (Fig. 6 Plina, Table 2). For analysed samples (VJ 10, VJ 15 and VJ 41) the ages were calculated as $7686 \pm 36 \mathrm{aBP}, 6836 \pm 36 \mathrm{aBP}$ and $1749 \pm 50 \mathrm{aBP}$, respectively.

\subsection{Geophysical investigation}

Four lithological members were distinguished from the top downwards: unit 1 - the natural resistivity is over $25 \mathrm{Ohmm}$; unit 2 the natural resistivity is under $20 \mathrm{Ohmm}$; unit 3 - the natural resistivity is between 50 and $150 \mathrm{Ohmm}$; unit 4 - the natural resistivity is over $150 \mathrm{Ohmm}$. The first geophysical unit corre- 


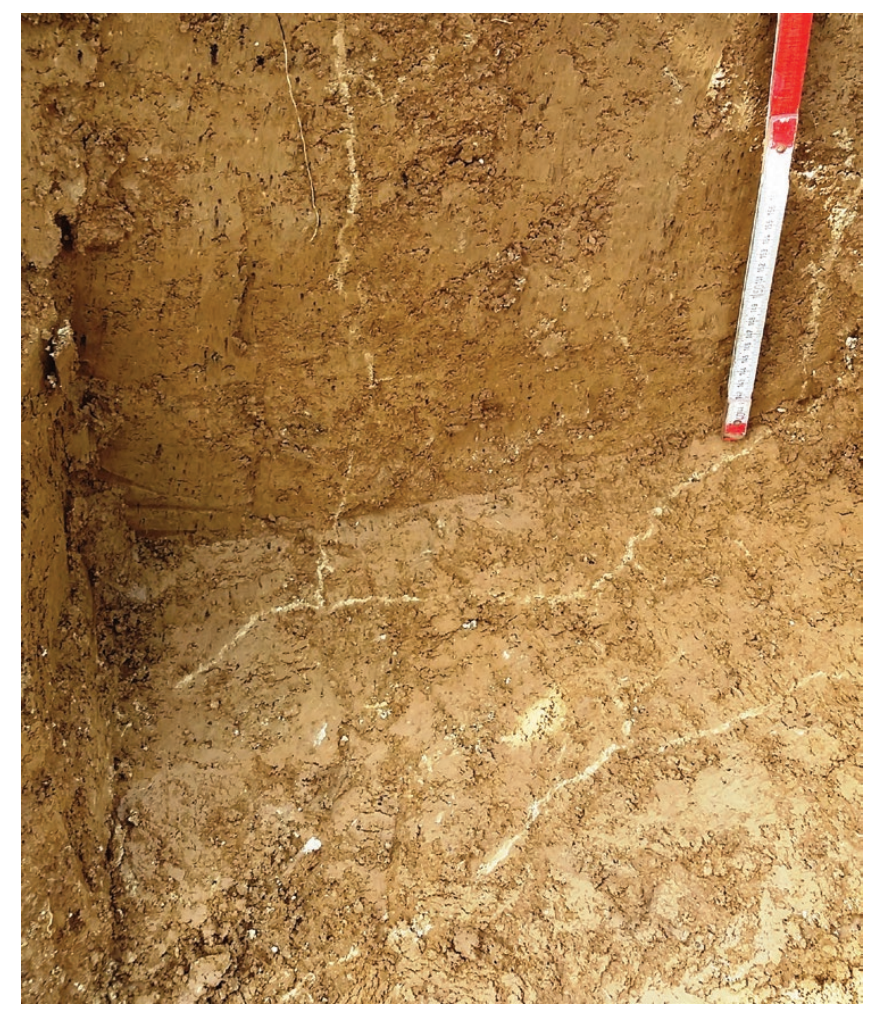

Figure 8. Desiccation cracks infilled with overlying lacustrine chalk. The white bar is $20 \mathrm{~cm}$.

sponds to the lacustrine chalk; the second unit shows the natural resistivity of clay; the third unit exhibits the geoelectric features of limestone breccia with clay matrix, and the fourth unit corresponds to limestone. Figure 10 shows the lithology reconstructed from the geoelectric profiles (LEUCCI, et al., 2004; TERZIĆ et al., 2007; ROMEY, et al., 2014; REY et al., 2017). The position of the profiles is shown in Figure 3.

\section{DISCUSSION}

At present, the Vrgoračko polje can be classified as a periodic lake formed within an enclosed internally-drained basin. Inflow into such poljes may come from surface streams, springs and estavelles (VALVASOR, 1689; PLENIČAR, 1954; SMREKAR, 2000; FORD \& WILLIAMS, 2007, p. 118). In the case of the Vrgoračko polje, the Matica River is a constant surface meandering stream charged by several springs, and in the wet seasons, the lake is inundated by springs and estavelles located along the NW edge of the polje.

In Apulia, Italy, the presence of numerous water supply wells was described in a geologically similar polje setting (LEUCCI et al., 2004). The dry Vrgoračko polje can become a lake within a few days (pers. comm. from residents). Thus, such a strong inflow of water to the lake could cause resedimentation
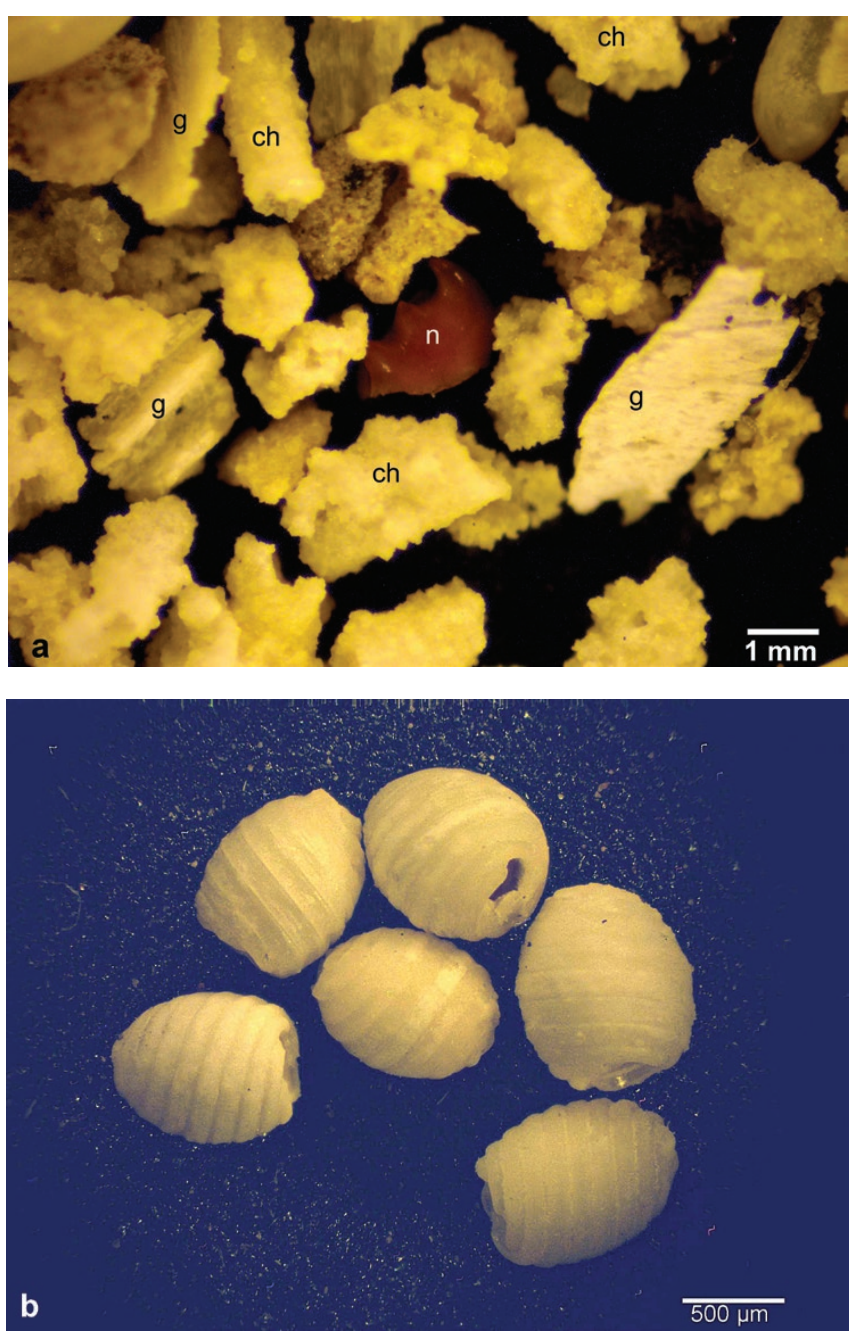

Figure 9.

A) Fossil remains of organisms that composed the lacustrine chalk in the Vrgorac polje: debris of characean thalli (ch), gastropod shells (g) and crab nipper (n); B) Characean gyrogonites.

of the topmost horizon. JARNUSZEWSKI \& MELLER (2018) noticed that a change of the environment from limnic to terrestrial, and a decrease in the lake level leads to the formation of characteristic morphological features such as cracks and numerous channels (Fig. 1). Thus, in the Vrgoračko polje, the surface of the polje can be presumed to have been erodable during intensive seasonal inflow. As the water-table level is high during winter, terrestrial slope sediments (colluvial debris and terra rossa) on the surrounding hills become flooded, altering the slope sediments in the littoral environment. As they were immersed in the water, they became lighter and, because of the clay content of terra rossa underlying colluvial debris (DURN, 2003; DURN et al., 2014), slippery. Sliding of slope sediments in winter-time along the littoral environment probably was more dy-

Table 2. Results of radiocarbon dating.

\begin{tabular}{|c|c|c|c|c|c|c|c|}
\hline \multirow{2}{*}{ DirectAMS code } & \multirow{2}{*}{ Submitter ID } & \multirow{2}{*}{$\begin{array}{l}\text { Hight above } \\
\text { the bedrock }\end{array}$} & \multirow{2}{*}{ Sample type } & \multicolumn{2}{|c|}{ Fraction of modern } & \multicolumn{2}{|c|}{ Radiocarbon age } \\
\hline & & & & $\mathrm{pMC}$ & Submitter ID & $\mathrm{BP}$ & $1 \sigma$ error \\
\hline D-AMS 018636 & VJ10 & $0.9-1.0$ & $\begin{array}{l}\text { gastropod } \\
\text { operculum }\end{array}$ & 38.41 & 0.17 & 7686 & 36 \\
\hline D-AMS 018637 & VJ15 & $1.4-1.5$ & $\begin{array}{l}\text { gastropod } \\
\text { operculum }\end{array}$ & 42.70 & 0.19 & 6836 & 36 \\
\hline D-AMS 018638 & VJ41 & $4.0-4.1$ & $\begin{array}{l}\text { gastropod } \\
\text { operculum }\end{array}$ & 80.43 & 0.50 & 1749 & 50 \\
\hline
\end{tabular}


namic than in summer-time on the dry shoreline slope. Such gravitational flows (TUCKER, 2008 p. 82) could be most intensive in the spring-time when the water-level is lowered: littoral sediment is not immersed in the lake water anymore, but it is still wet, heavy and slippery. Water outflow through estavelles and ponors into the Neretva River and the artificial Prigon tunnel into the Baćinska Lakes would have resulted in erosion of the lake floor, through rapid-flow runoff (FORD \& WILLIAMS, 2007, p. 181-182).

The investigated sediments indicate environmental variability and dynamics in this karstic field during the Holocene. According to READING (1996) and TUCKER (2008), environment is a complex of physical, chemical and biological conditions (which are not wholly independent) at a given period of time in a given local area. Sedimentary facies are bodies of sediment that are recognizably distinct from adjacent sediments that resulted from different depositional environments. However, as a result of studies of Holocene sediments, there has been increasing emphasis on the study of the vertical organization of lithologies and structures - the lithologic package (PETTIJOHN, 1975; DEINO et al., 2006; KINGSTON et al., 2007; NOBLE et al., 2015; BAKER et al., 2018;). The vertical sequence of sedimentary facies is not random but is, instead, organized in a coherent and predictable way. Therefore, recognition of the vertical arrangement itself, which places the individual facies and their sedimentary structures in a meaningful sequence or package, enables us to reconstruct a detailed picture of interaction in specific palaeoenvironments (PETTIJOHN, 1975).

On the basis of the presented results, two main depositional environments could be identified: aquatic (lacustrine) and terrestrial.

In aquatic environments, five sedimentary facies are recognized (Fig. 11):

A) Lacustrine deeper-water depositional environment

Facies: 1-laminated sediment, 2-redeposited sediment.

B) Lacustrine littoral depositional environment

Facies: 1-coarse-grained carbonate debris, 2-littoral clay, 3-lacustrine chalk.
The terrestrial environment is:

C) Desiccated lake environment

This single facies is documented by the presence of desiccation cracks, erosion surfaces, palaeosols and reworked littoral facies.

\subsection{Lacustrine deeper-water depositional environment}

\subsubsection{Facies of laminated sediments}

In the deeper part of the lake, laminated sediments were deposited from suspension as indicated by their grain size (TUCKER, 2008 p. 253-255). According to geoelectric profiles, the boreholes are located in the part of the Vrgoračko polje where the Quaternary sediments are the thickest (Figs. $3 \& 10$ ). The laminated sediments (the second geophysical unit) were only observed there, and results of geoelectrical measurements indicate that the thickness of these, or similar, sediments in the NE area of the polje exceed 60 metres (Figs. 3, $5 \& 10$ ). The second geophysical unit shows the natural resistivity of clay, and there are no data indicating a possible change in the lithological composition of deeper sediments. Accordingly, on the basis of the lithological determination of the deepest samples from drill-cores, it could be presumed that the whole 60 metres of Quaternary clays belong to the deep-water laminated facies. FORD \& WILLIAMS (2007, p. 276) reported that clays and silts usually accrete as laminae parallel to the depositional surface. There may be a marked fining upwards within a single lamina, which creates a colour change that gives it the appearance of a couplet in many glaciated regions. Aggregate sections can total many metres (FORD \& WILLIAMS, 2007). With a high degree of certainty, this sediment can be recognised as varves. Varve sedimentation reflects seasonal changes in the environment (SCHEIDEGGER, 1965; O'SULIVAN, 1983; ZOLITSCHKA, 2013; ZOLITSCHKA et al., 2015; TRAPOTE et al., 2018; ŞIMŞEK \& ÇAĞATAY, in press).

This facies has an erosional contact with overlying sediments redeposited in the deeper lacustrine facies with a noticeable increased quantity and character of soft-sediment deformation (SSD) (Fig. 7). If the erosional contact is related to tectonic events, it could be presumed that SSD in the underlying facies
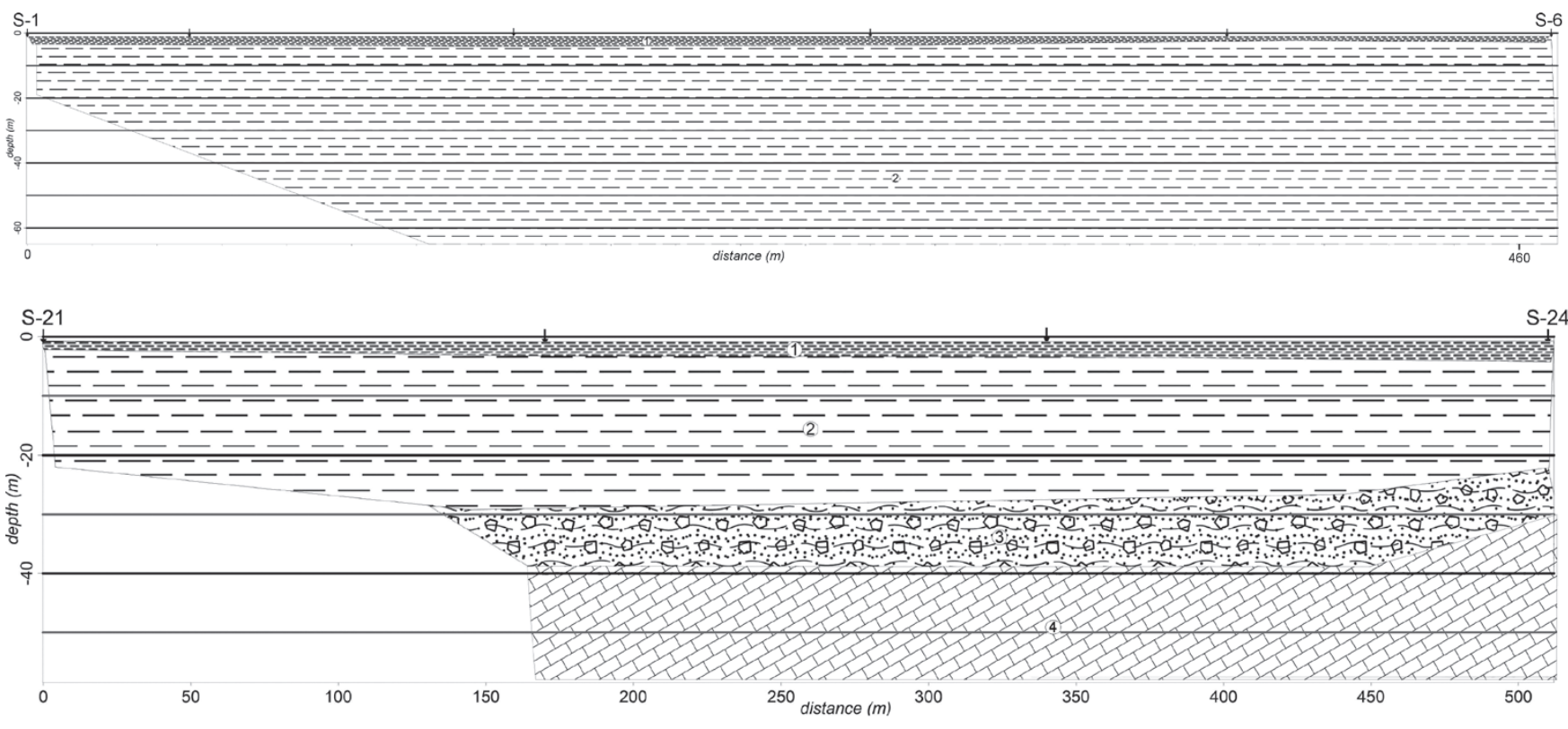

Figure 10. Lithological profiles S1-S6 and S21-S24 reconstructed from the geoelectric resistivity measurements. The legend in Figure 11., and the positions of the profiles in Figure 2. 
were not related to earthquakes, whereas SSD in overlying facies could be related to earthquakes (RUDERSDORF et al., 2015; LUNINA \& GLADKOV, 2016; SHANMUGAM, 2017).

\subsubsection{Facies of sediments redeposited in the deeper lacustrine facies}

Disturbed clayey and carbonate sediments contain plasticallydeformed laminated clasts, lacustrine chalk and clays with limestone fragments (Fig. 7). These were presumably carried by water currents or mud flow, and their movement could be the result of slope movement, mud flow and/or rain flash flood (comparable to reports of REINECK \& SINGH, 2012). Interbedded shallow lacustrine sediments and SSD assigned to palaeoseismic triggering provide strong evidence for the seismic origin of the deformation (RUDERSDORF et al., 2015).

Based on the investigation of Pleistocene-Holocene sediments in the Northeastern Ejina Basin, Inner Mongolia (a lake environment) (RUDERSDORF et al., 2015), water-escape structures, folds, convolution, dish structures and small-scale intraformational faults were recognized as earthquake-induced structures (SHANMUGAM, 2017). Furthermore, clastic injections in a modern lake in the Bajkal region and load casts and convolute lamination from the Late Pleistocene in the Issyk-Kul Lake, Central Asia (LUNINA \& GLADKOV, 2016) are described as a reliable indicator of earthquake-induced structures in modern environments (SHANMUGAM, 2017).

Alternations of carbonate intercalations in the clay sediments and clay intercalations in the lacustrine chalk sediments were probably deposited by water outflow due to extensive erosion of the clay and lacustrine chalk (Fig. 7a). Such erosion could be triggered by an earthquake (TUCKER 2008). Based on the geometry of the polje and field observations, general transport directions are from the north west of Vrgoračko polje and locally from a shallow to deeper water environment. Numerous Cretaceous limestone fragments were washed from colluvial sediments on shore, but also from littoral clays. An absence of clay lamination and fining-up structure could lead to the conclusion that they were decanted from a homogeneous suspension that was steadily renewed. Littoral clay most probably originates from reworked terra rossa from the drainage basin of the Vrgoračko polje. Investigation of mineralogy and geochemistry of terra rossa in the Dinarides suggests its polygenetic origin (DURN, 2003; DURN et al., 2014).

Plastically deformed clasts and curved laminae within the clasts indicate underwater erosion (ALLEN, 1982; VAN LOON \& BRODZIKOWSKI, 1987; AVŞAR et al., 2016; SHANMUGAM, 2017). It could be assumed that mud clasts were ripped up from the shallow lake floor by strong water currents, rounded and deposited in deeper water. In addition, erosional discontinuities between alternating lithologically different layers in the facies indicate sudden environmental change from calm deep-water varved sedimentation to a strong mud flow. This is visible in Figure $7 \mathrm{~b}$, where laminated clays show SSD structures floating in a lacustrine chalk matrix. Clay clasts and lacustrine chalk could have been eroded by strong flow and redeposited over deepwater laminated facies. Later, littoral clays with limestone fragments were redeposited on the top of this succession (Fig. 7b).

\subsection{Lacustrine littoral depositional environment}

\subsubsection{Coarse-grained carbonate debris in shallow-water} facies

The whole perimeter of the Vrgoračko polje is defined by strong fault systems (Fig. 3) and many of them are neotectonic and still active (CVIJANOVIĆ et al. 1981; BOŽIČEVIĆ \& BENČEK,

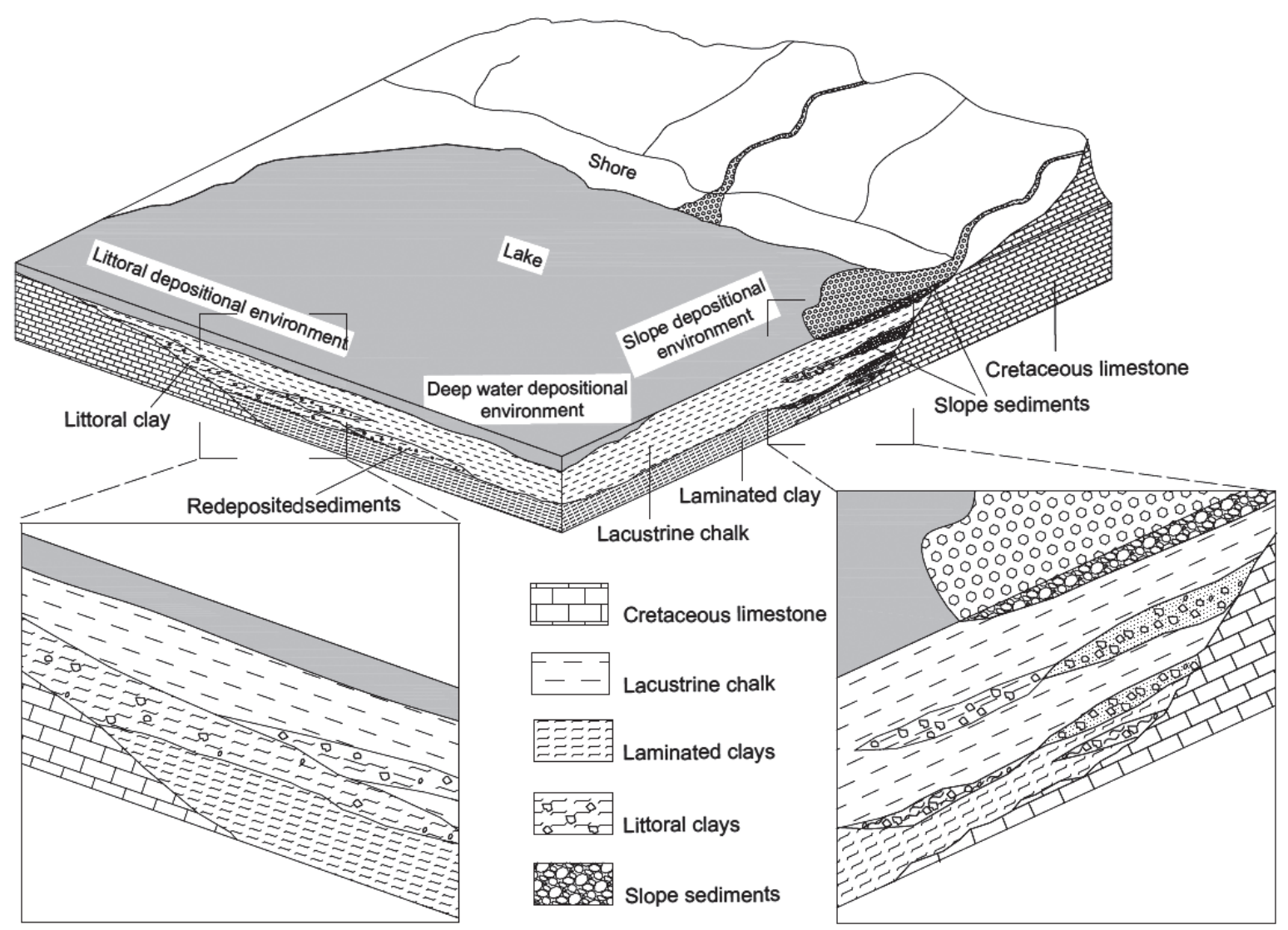

Figure 11. Reconstruction of the depositional environments in the Vrgoračko Polje Lake. Not to scale. 
1983; HERAK et al. 1995, 1996; BLAŠKOVIĆ, 1998; DRAGIČEVIĆ et al. 1999). An especially active zone is located in the SE part, where recent colluvial fans have prograded into the polje. The whole facies association (see section 4.1.3. a-c) is the result of slope processes of sliding and sediment-gravity flow movements. Very poorly sorted breccia could be colluvial material that prograded into the ancient lake by the mechanism of detrital flow (TUCKER, 2008 p. 82).

Wave activity on beaches around the lake margin could round angular clasts of colluvial material to various degrees (Fig. 12) and form breccia-conglomerate; alternatively, clasts were subrounded by palaeoflow and then cemented. This could be supported by terrestrial gastropod shells discovered in the matrix. In view of the poorly-graded clasts within the colluvial deposits, it can be assumed that the material was transported quickly by flows in a strong hydrodynamic regime. It is well described as detrital flow (TUCKER, 2008 p. 82). Later, this material could have been reworked by a stream and flash floods and resedimented as alluvium. This presumption is based on the sorting, roundness and imbrication of clasts. It formed the clast-supported well-sorted conglomerate, probably in a fan form. A-axis clast imbrication, with longer clast axis parallel to the stream flow, is typical for a rapidly-decreasing suspension flow (POTTER \& PETTIJOHN, 1977; REINECK \& SINGH, 2012), which would have transported material from the lake shore.

A different sedimentation process is recorded in the clasts intercalated in clay or lacustrine chalk (see section 4.1.3. d). Based on the conspicuous erosional contact with underlying sediments, this sediment body is probably the result of a very dynamic event, which could be described as debris or mud flow. Debris or mud flows could have started from colluvial sediments accumulating on top of littoral clays. Littoral clays could be the source material for the clayey part of the matrix. Colluvium weight and some initiating event (such as rain, the annual lake inundation or earthquake) could result in a debris flow (TUCKER, 2008 p. 81-82) (as mentioned in the introductory paragraph of the discussion). If the debris was mixed with littoral clay, the material might continue moving as a mud flow (TUCKER, 2008 p. 82). The flow could incise the channel in the underlying clays and lacustrine chalk.

Coarse-grained carbonate debris in shallow-water facies (SE part of the polje, the Špila section) (Fig. 6) has an erosional contact with the underlying sediments followed by sedimentation of the overlying lacustrine chalk. In all the other studied sections, lacustrine chalk has an erosional contact with underlying sediment (Fig. 6).

\subsubsection{Littoral clay facies}

The main feature of littoral clays is that they are structureless and fill depressions and caverns in the karst relief in the shallower part of the palaeolake. FORD \& WILLIAMS (2007) call them residual clays. They are massive and thick, generally darker than the sediments redeposited in the deeper lacustrine facies (Table 1). However, these clays also contain corroded Cretaceous limestone fragments, Fe-Mn concretions and gastropod opercula. Therefore, based on composition, these littoral clays could be the source material for sediments redeposited in the deeper lacustrine facies. Their Pleistocene age was presumed based on the principle of superposition (MAGAŠ et al., 1972). The gastropod opercula were recrystallized and unsuitable for dating.

However, although dark, numerous remains of the gastropod Bithynia tentaculata and intensive bioturbation indicate an oxic environment with intensive benthic life (BOS et al., 2017). There are two possible scenarios for the evolving oxic/anoxic environment: a) periodic deoxygenation and acidification of the littoral environment and b) shallow oxygenation of the pore water in the sediment column during low water-level. It is very likely that both scenarios could occur. During the periods of lower input of oxygenated water, oxygen consumption by living organisms and decaying organic matter can become problematic. As decaying organic matter consumes oxygen it also at the same time increases water acidity (BASTVIKEN et al., 2004). The period of dark lamina formation in deep-water laminated clays could correspond to an anoxic acidic period in the littoral environment.

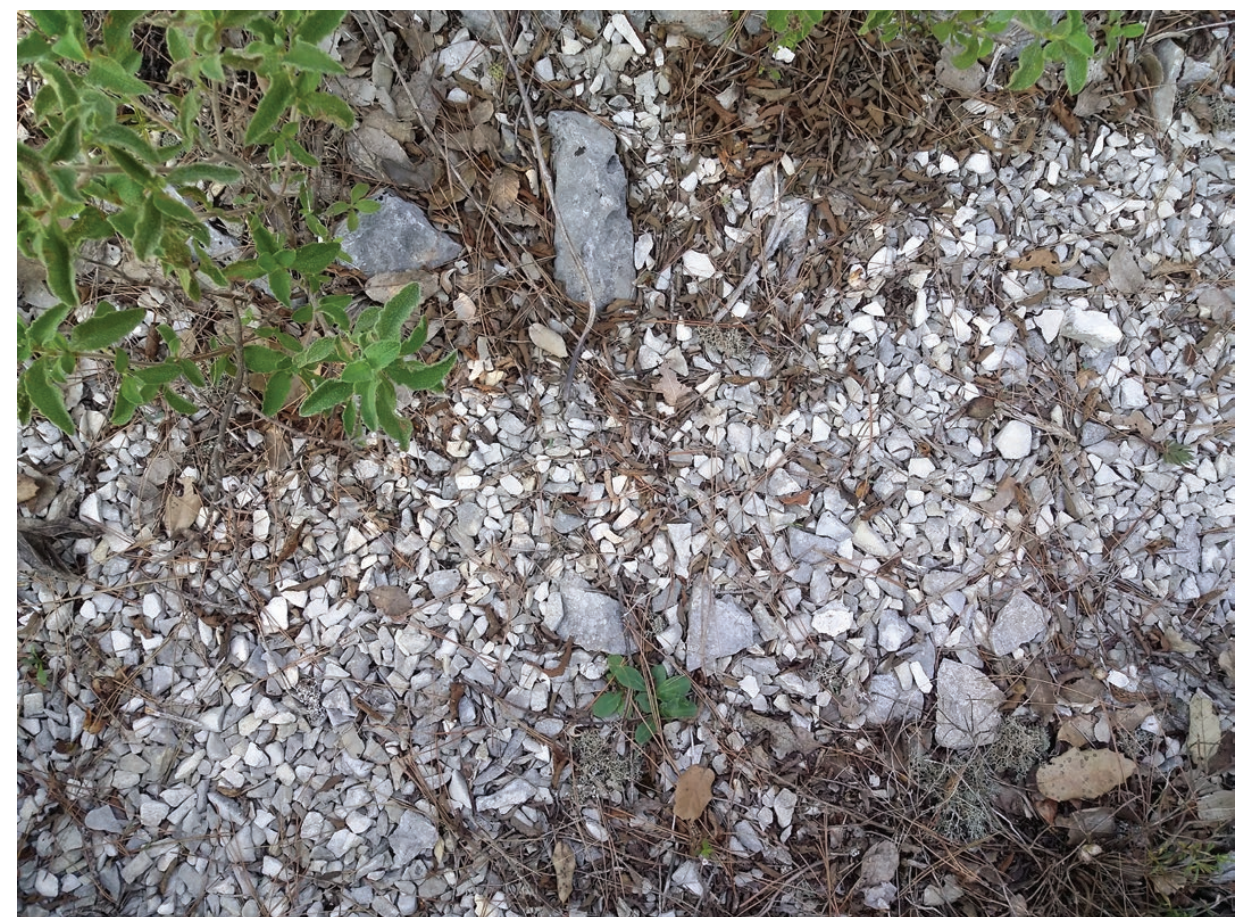

Figure 12. Detail of the modern shore-line around the lake margin during winter. 
The gastropod Bithynia tentaculata inhabits lakes and ponds with standing or low-velocity water circulation (WEEKS et al., 2017). This gastropod lives in water up to five metres deep in the littoral zone, grazing on the bottom or on aquatic plants. It is interesting to point out that Bithynia can also feed by filtering water, which allows a high population density to survive in eutrophic and shallow water (CLARKE, 1979; DILLON, 2000). Sedimentological and archaeological data (the presence of palaeosols and desiccation cracks in the profile and the cemetery in the low part of the polje) indicate that lake water-level periodically decreased and in some parts completely dried up. As it is an invasive gastropod (WEEKS et al., 2017), an almost monospecific gastropod fauna existed in the lake.

\subsubsection{Lacustrine chalk facies}

Carbonate deposition in lakes is sensitive to climatic and tectonic influences and dependent upon lake hydrology and morphology. Climate controls the rate and nature of biogenic productivity, influences chemical weathering, erosion and runoff rates in the catchment area, and thus determines carbonate supply (PLATT \& WRIGHT, 1991). Almost the whole area of the Vrgoračko polje is covered by chalk sediment and it occurs above all other sedimentary facies. Thus, the depositional environment of the lacustrine chalk was the last stage of the lake life cycle (Fig. 5). Characeae grow in the littoral zone, usually up to 10 or 15 metres water depth (SOULIE-MARSCHE \& GARCIA, 2015), with a maximum recorded depth of 30 metres (BEILBY \& CASANOVA, 2014). This type of intensive primary carbonate production was confined to the littoral zone, but significant amounts of resedimentation to the deeper-water environment could occur. During the annual rapidflow runoff of lake water (FORD \& WILLIAMS, 2007, p. 181-182), fragile characeae thalli could be rinsed and redeposited towards ponors or estavelles. The difference in the floor altitude of the polje is $8 \mathrm{~m}$. At the Plina section, there are 3.8 metres of characean carbonate (Figs. $1 \& 4$ ). The transitional horizon between the littoral clays and lacustrine chalk was erosional and intensively bioturbated, showing an increased carbonate content in the prevailing clayey sediments of the transitional horizon (Fig. 5).

The lacustrine chalk facies in the Vrgoračko polje in the previous study was termed Lacustrine chalk (MAGAS̆ et al., 1972; MARINČIĆ et al., 1972). The grain size of lacustrine bioclasts from the Vrgoračko polje (up to $3 \mathrm{~mm}$ ) significantly differs from marine chalk with grains less than 10 micrometres in size (e.g. coccoliths; TUCKER \& WRIGHT, 1990) or aragonite mud (SONDI \& JURAČIĆ, 2010). JARNUSZEWSKI \& MELLER (2018) described Holocene lacustrine chalk from NW Poland as fine crystalline calcite which, when moistened, forms a type of gel. Since the facies in our investigation is dominated by characeae thalli (see section 4.1), in order to avoid any misinterpretation, we could use the term introduced by SOULIE-MARSCHE et al. (2010) of Characeite.

The rate of sedimentation:

Characean algae assimilate $\mathrm{CO}_{2}$ from bicarbonate ions during photosynthesis. As a result, calcium carbonate is precipitated on the surface of the thallus (BEILBY \& CASANOVA, 2014, SOULIEMARSCHE \& GARCIA, 2015). Charophytes are extremely successful at calcite precipitation and can be the most important factor in carbonate precipitation in some lakes. PENTECOST (1984) found that some species of characea can produce annually up to $1100 \mathrm{~g}$ of calcium-carbonate per square metre, but the average value of precipitated calcite for different species is more than $400 \mathrm{gm}^{-2}$ $\mathrm{a}^{-1}$ (PEŁECHATY et al., 2013; APOLINARSKA et al., 2011).
Based on the ${ }^{14} \mathrm{C}$ dates from three horizons in characean carbonate from the Plina section, the average sedimentation rates in the lake can be calculated. The sediment thickness between the oldest date of $7686 \pm 36 \mathrm{aBP}$ and the intermediate date of $6836 \pm 36$ aBP is $500 \mathrm{~mm}$ (Fig. 6, Table 2). This gives a sedimentation rate of $0.58 \mathrm{~mm} \mathrm{a}^{-1}$. Between the intermediate and the youngest date, during 5087 years, $2600 \mathrm{~mm}$ of characeite were deposited, with a sedimentation rate of $0.51 \mathrm{~mm} \mathrm{a}^{-1}$. The similar sedimentation rates could indicate an almost constant rate of characean carbonate production. This small decrease in sedimentation rate could be explained by periodic desiccation of the Vrgoračko polje during the Late Holocene (see section 5.3.) that interrupted carbonate production in a well-balanced lake ecosystem. Based on the measured specific mass of the sediment and the sediment volume, carbonate production is estimated to have been $1050 \mathrm{gm}^{-2} \mathrm{a}^{-1}$. Calculated carbonate mass is in the range measured for recent characea by PEŁECHATY et al. (2013) and APOLINARSKA et al. (2011). Generally, the sediment is not much altered by diagenesis. Water $\mathrm{pH}$ in the lake was elevated and probably buffered to a relatively constant value by an excess of easily soluble calcium-carbonate material.

\subsection{Depositional environment of the periodically desiccated lake}

In the deepest part of the Vrgoračko polje (the Plina section) two palaeosols were developed on characeite. Thus, it can be presumed that the lake has been at least twice partially desiccated. During desiccation, erosion could become the main sedimentological process in the polje (DAURA et al., 2017) and the material resedimented into the deeper parts of the basin. Characeite is an easily erodible material (Fig. 1). In detail, before seasonal or periodic desiccation and water-level fall, the sediment surface remained protected under the cover of aqueous algal remains. During the decay time of the algal remains, the new growth of terrestrial grass could protect the sediment from further erosion (JARNUSZEWSKI \& MELLER, 2018). If the top horizon was exposed to strong inflow from the bottom of the lake (springs and estavelles) (FORD \& WILLIAMS, 2007; MORELLÓN et al., 2014), local streams could remove the protective vegetation cover, and channels could be rapidly formed by erosion. Widening and deepening of a channel could be fast. When the channel network was formed, individual channels intersected, merged and separated their flows, as occurs today. The result was indented, irregular relief with steep slopes. At present, in the Vrgoračko polje, such erosion takes place in very narrow areas (Fig. 1), but erosional processes are very intense since the annual outflow of the water is rapid (pers.comm. from residents).

If sediment is exposed above the water-level long enough, pedogenic processes occur. Palaeosol intercalations in characeite are brown, intensively bioturbated clays, indicating an abundant in-fauna (RETALLACK, 2001). Most of the bioturbation can be attributed to back-filled earthworm burrows (RETALLACK, 2001). Pedogenesis is documented in the Plina section in samples VJ 23 and VJ 28-29 (Fig. 6). Based on interpolation of ${ }^{14} \mathrm{C}$ data and the sedimentation rate, the older palaeosol, could be dated at $5170 \mathrm{aBP}$, and the younger one at $3600 \mathrm{aBP}$.

Desiccation cracks at the bottom of the characeite in the Plina section indicate a temporary phase of subaerial exposure of the lake older than $7686 \pm 36$ years BP (Figs. 6 \& 8).

Occasional lake shallowing and partial desiccation events could also be reflected in the decrease of biogenic carbonate content in the sediment. There are two possible explanations: older 
clay sediments were eroded and resedimented into the deeper lake zone and/or the production of biogenic (characean) carbonate decreased or stopped. A horizon without bioturbation was recognised in the Plina section and is presented in Figure 6 (sample VJ 31).

When the characean carbonate content decreased and the percentage of siliciclastic detrital components increased, numerous Bithynia tentaculata opercula would appear. Consequently, the development of the Bithynia population could indicate an increase in the extent of the shallow littoral zone (JOHNSON et al., 2018), i.e. an increase of Bithynia remains in sediment could be an indication of shallowing of the lake.

In the Plina section, the entire characeite interval is radiocarbon dated to the Holocene. The oldest dated sample from the first $10 \mathrm{~cm}$ interval of the characeite $(7686 \pm 36 \mathrm{aBP})$ on the Plina section was deposited at the beginning of the Mid-Holocene Warm Period (WALKER et al., 2012). With the climate change during the Holocene (WALKER et al., 2012; SURIĆ. \& JURAČIĆ, 2010), environmental conditions could have become favourable for the intensive growth of characean algae. If characean algae, with their mass carbonate production, significantly accelerated lake shallowing (SOULIE-MARSCHE \& GARCIA, 2015; SOULIE-MARSCHE et al., 2010), the wider shore areas could have caused more intensive erosion and resedimentation into deeper lake zones.

Although underlying the disturbed clayey and carbonate sediments, the laminated clay and littoral clays are not dated because the material is unsuitable for dating. However, it could be presumed that they were deposited during the Pleistocene and Early Holocene. The underlying littoral clay at the same location is up to $10 \mathrm{~m}$ thick. The sub-millimetre varve structure and sedimentation mechanism of the suspended material indicate a slow rate of sedimentation and consequently a longer time interval for their formation. On the basis of the geophysical profile S 21-24 (Fig. 10b) and the Plina and Umčani sections, the southwestern area of the Vrgoračko polje can be characterized as a shallower depositional environment with a slightly inclined wide littoral zone, where littoral clays were deposited (REY et al., 2017).

Similar to the poljes located in the Idria fault system (Slovenian Dinarides) (PLENIČAR, M., 1954; SMREKAR, 2000; VRABEC, 1994), the hydrological regime and water level of the Vrgoračko polje during the Holocene could have been changed due to karstification processes and/or neotectonic movements. More intensive neotectonic movements on the NE margin of the Vrgoračko polje (CVIJANOVIĆ et al., 1981; BOŽIČEVIĆ \& BENČEK, 1983; HERAK et al., 1995, 1996; BLAŠKOVIĆ, 1998; DRAGIČEVIĆ et al., 1999) could have caused rapid lake-floor subsidence in that area. In such a deeper-water environment, laminated sediments could accumulate. Active neotectonics initiated the formation of colluvial material that was reworked by water and slid into the lake, and today remains as channel fills and alluvial fan facies (LUNINA \& GLADKOV, 2016; MULDER \& SYVITSKI, 1995; RUDERSDORF et al., 2015). VRABEC (1994) reported a pull-apart origin for the karst poljes along the Idrija strike-slip fault zone (the Cerkniško polje). He claimed that neotectonic movements could have caused rapid subsidence that would have undoubtedly produced significant sediment accumulations, at least in the form of marginal talus and debris fans. Such movements could have caused more intensive sedimentation and a more diverse vertical sequence of sedimentary facies in the NE rather than in the SE part of the Vrgoračko polje.

\section{CONCLUSIONS}

Quaternary sediments of the Vrgoračko polje represent a record of diverse environments which existed in the area and evolved during the Holocene, with the probable beginning of sedimentation during the Pleistocene. The whole perimeter of the Vrgoračko polje is defined by strong fault systems and many of them are neotectonic and still active. In that periodically inundated polje (lake), three main sediment packages reflect the variability and dynamics of the environment in this polje: deeper-water lacustrine, littoral lacustrine and desiccated lake environments.

According to geoelectric profiles, the lacustrine deeper-water deposits could be composed of more than $60 \mathrm{~m}$ of varved lake sediments with soft sediment deformation horizons. Erosion and local re-sedimentation of underlying sediments with a significant inflow of surrounding slope sediments correspond to tectonic events that could have changed the hydrological regime of the Vrgoračko polje and initiated debris and mud flows. These disturbed clayey and carbonate sediments are composed of alternating carbonate intercalations in the clay sediment and clay intercalations in the lacustrine chalk. Alternations are marked by erosional contacts. It is assumed that mud clasts were ripped up from the shallow lake floor by strong water currents, rounded and deposited in deeper water. Intercalations of clay contain coarser corroded Cretaceous limestone fragments. Based on the principle of superposition, this set of sediments were redeposited in the deeper lacustrine facies, as reliable earthquake-induced structures, and could be correlated with coarse-grained carbonate debris in shallow-water facies in the littoral depositional environment. The whole facies association (ranging from clast-supported very poorly sorted breccia to well-sorted conglomerate and clasts intercalated in clay or lacustrine chalk) is colluvial material that could prograde into the ancient lake by the mechanism of detrital flow, and could form an erosional contact with underlying sediments. Littoral clay filled depressions and caverns in the karst relief in the shallower part of the lake. They are bioturbated and massive, containing corroded Cretaceous limestone fragments, $\mathrm{Fe}-\mathrm{Mn}$ concretions and gastropod opercula.

The lacustrine chalk facies is the most widespread and the youngest sediment in the Vrgoračko polje. The chalk (characeite) is composed approximately of $80 \%$ authigenic characean carbonate; $15 \%$ of gastropod opercula, gastropod and ostracod debris and the rest is siliciclastic detritus. Based on ${ }^{14} \mathrm{C}$ analysis, this facies was formed around $7686 \pm 36$ years BP. A calculated sedimentation rate during the Middle Holocene is approximately 0.58 $\mathrm{mm} \mathrm{a}^{-1}$ and during the Late Holocene $0.51 \mathrm{~mm} \mathrm{a}^{-1}$. Similar sedimentation rates could indicate an almost constant rate of characean carbonate production. This small decrease in sedimentation rate could be reflected in the periodic desiccation of the Vrgorac Lake during the Late Holocene, documented by the presence of palaeosols and desiccation cracks. Based on interpolation of ${ }^{14} \mathrm{C}$ data and sedimentation rate, the older palaeosol could be $5170 \mathrm{aBP}$ in age, and the younger one $3600 \mathrm{aBP}$ in age. Furthermore, a temporary phase of subaerial exposure of the lake, indicated by desiccation cracks, is older than $7686 \pm 36$ years BP.

On the basis of the measured specific mass of the sediment and the sediment volume, the calculated carbonate production is estimated at $1050 \mathrm{gm}^{-2} \mathrm{a}^{-1}$.

\section{ACKNOWLEDGMENT}

This work has been fully supported by the Croatian Science Foundation under the project SAPIQ 4425. The authors are 
very grateful to Associated Editor, Mladen JURAČIĆ and reviewers Maurice TUCKER, Ingeborg SOULIÉ-MÄRSCHE and Davor PAVELIĆ for providing us with valuable and constructive reviews of our work. We have found lots of useful guidelines in the comments that improved our manuscript.

\section{REFERENCES}

ALLEN, J.R.L. (1982): Sedimentary Structures Their Character and Physical Basis.- In: ALLEN, J.R.L. (ed.): Chapter 9 Soft-Sediment Deformation Structures. Developments in Sedimentology, 30B/ II.- Elsevier, Amsterdam, 343-393, 663 p. doi: 10.1016/S0070-4571(08)71019-7

APOLINARSKA, K., PELECHATY, M. \& PUKACZ, A. (2011): CaCO3 sedimentation by modern charophytes (Characeae): can calcified remains and carbonate $\delta 13 \mathrm{C}$ and $\delta 18$ O record the ecological state of lakes? A review.- Stud. Limnol. Telmatol., 5, 55-66.

AVŞAR, U., JÓNSSON, S., AVŞAR, O. \& SCHMIDT, S. (2016): Earthquake-induced soft-sediment deformations and seismically amplified erosion rates recorded in varved sediments of Köyceğiz Lake (SW Turkey).- Journal of Geophysical Research: Solid Earth, 121/6, 4767-4779. doi: 10.1002/2016JB012820

BAKER, A., ROUTH, J. \& ROYCHOUDHURY,A.N. (2018): n-Alkan-2-one biomarkers as a proxy for palaeoclimate reconstruction in the Mfabeni fen, South Africa.- Organic Geochemistry, 120, 75-85. doi: 10.1016/j.orggeochem.2018.03.001

BASTVIKEN, D., PERSSON, L., ODHAM, G. \& TRANVIK, L. (2004): Degradation of dissolved organic matter in oxic and anoxic lake water-- Limnol. Oceanogr., 49/1, 109-116. doi: 10.4319/1o.2004.49.1.0109

BEILBY, M.J. \& CASANOVA, M.T. (2014): The physiology of characean cells.- Springer-Verlag Berlin Heidelberg, 205 p. doi: 10.1007/978-3-642-40288-3

BLAŠKOVIĆ, I. (1998): The two stages of structural formation of the coastal belt of the External Dinarides.- Geol. Croat., 51/1, 75-89.

BOGGS, S.J.R. (2013): Principles of Sedimentology and Stratigraphy: New International Edition (5e).- Pearson Higher Ed USA, $568 \mathrm{p}$

BOS, J.A.A., DE SMEDT, P., DEMIDDELE, H., HOEK, W.Z., LANGOHR, R., MARCELINO, V., VAN ASCH, N., VAN DAMME, D., VAN DER MEEREN, T., VERNIERS, J., BOECKX, P., BOUDIN, M., COURT-PICON, M., FINKE, P., GELORINI, V., GOBERT, S., HEIRI, O., MARTENS, K., MOSTAERT, F., SERBRUYNS, L., VAN STRYDONCK, M. \& CROMBÉ,P. (2017): Multiple oscillations during the Lateglacial as recorded in a multi-proxy, high-resolution record of the Moervaart palaeolake (NW Belgium).- Quat. Sci. Rev., 162, 26-41. doi: 10.1016/j.quascirev.2017.02.005

BOŽIČEVIĆ, S. \& BENČEK, Đ. (1983.): Tektonsko - geomorfološke specifičnosti Biokova i pojave urušnih vrtača i ledenica.- Acta Biokovica, 2, 157-166.

CLARKE, A.H. (1979): Gastropods as indicators of lake trophic stages.- The Nautilus, 94/4, 138-142.

CURRIE, L.A. (2004): The Remarkable Metrological History of Radiocarbon Dating [II].Journal of Research of the National Institute of Standards and Technology, 109, 185-217. doi:10.6028/jres.109.013

CVIJANOVIĆ, D., ARSOVSKI, M. \& MIHAILOV, V. (1981): Karakteristike seizmičke aktivnosti u širem području Biokova-- Acta Biokovica, 1, 23-34.

DAURA, J., SANZ, M., ALLUÉ, E., VAQUERO, M., LÓPEZ-GARCÍA, J.M., SÁNCHEZ-MARCO, A., DOMÈNECH, R., MARTINELL, J., CARRIÓN, J.S., ORTIZ, J.E., TORRES, T., ARNOLD, L.J., BENSON, A., HOFFMANN, D.L., SKINNER, A.R. \& JULIÀ, R. (2017): Palaeoenvironments of the last Neanderthals in SW Europe (MIS 3): Cova del Coll Verdaguer (Barcelona, NE of Iberian Peninsula).-- Quat. Sci. Rev., 177, 34-56. doi: 10.1016/j.quascirev.2017.10.005

DEINO, A.L., KINGSTON, J.D., GLEN, J.M., EDGAR, R.K. \& HILL, A. (2006): Precessional forcing of lacustrine sedimentation in the late Cenozoic Chemeron Basin, Central Kenya Rift, and calibration of the Gauss/Matuyama boundary.- Earth and Planetary Science Letters, 247/1-2, 41-60. doi: 10.1016/j.eps1.2006.04.009

DILLON, R.T. (2000): The Ecology of Freshwater Molluscs.- Cambridge University Press, Cambridge, 509 p. doi: 10.1017/CBO9780511542008

DRAGIČEVIĆ, I., PRELOGOVIĆ, E., KUK, V. \& BULJAN, R. (1999): Recent tectonic activity in the Imotsko polje area.- Geol. Croat., 52/2, 191-196.

DURN, G., ĆORIĆ, R., TADEJ, N., BARUDŽIJA, U. \& RUBINIĆ, V. (2014): Bulk and clay mineral composition indicate origin of terra rossa soils in Western Herzegovina.- Geol. Croat., 67/3, 171-183. doi: 10.4154/GC.2014.13

DURN, G. (2003): Terra rossa in the Mediterranean region: parent materials, composition and origin.- Geol. Croat., 56/1, 83-100.

FORD, D.C. \& WILLIAMS, P. (2007): Karst Hydrogeology and Geomorphology.- Wiley \& Sons, Chichester, England, 562 p. doi: 10.1002/9781118684986

HERAK, MA., HERAK, D. \& MARKUČIĆ, S. (1995): Fault-plane solution for earthquake (1956-1995) in Croatia and neighbouring regions.- Geofizika, 12, 43-56.

HERAK, MA., HERAK, D. \& MARKUČIĆ, S. (1996): Revision of the Earthquake catalogue and seismicity of Croatia, 1908-1992.- Terra Nova, 8, 86-94. doi: 10.1111/ j.1365-3121.1996.tb00728.x

HERAK, Mi. (1986): A New Concept of Geotectonics of the Dinarides.-Acta Geologica, $16 / 1,1-42$
HERAK, Mi. (1991): Dinaridi, mobilistički osvrt na genezu i strukturu [Dinarides - mobilistic view of the genesis and structure - in Croatian].-Acta Geologica, 21/2, 35117

JARNUSZEWSKI, G. \& MELLER, E. (2018): Morphological and Physical Properties of Dehydrated Holocene Carbonate Limnic Deposits in Post-Bog Areas of NW Poland.-Journal of Ecological Engineering, 19, 136-142. doi:10.12911/22998993/79412

JOHNSON, R.K., HALLSTAN, S. \& ZHAO, X. (2018): Disentangling the response of lake littoral invertebrate assemblages to multiple pressures.- Ecological Indicators, 85, 1149-1157. doi: 10.1016/j.ecolind.2017.10.075

KINGSTON, J.D., DEINO, A.L., EDGAR, R.K. \& HILL, A. (2007): Astronomically forced climate change in the Kenyan Rift Valley 2.7-2.55 Ma: implications for the evolution of early hominin ecosystems.- Journal of Human Evolution, 53/5, 487-503.

LEUCCI, G., MARGIOTTA, S. \& NEGRI, S. (2004): Geophysical and Geological Investigations in a Karstic Environment (Salice Salentino, Lecce, Italy).- Journal of Environmental and Engineering Geophysics, 9/1, 25-34. doi: 10.4133/JEEG9.1.25

LUNINA, O.V. \& GLADKOV, A.S. (2016): Soft-sediment deformation structures induced by strong earthquakes in southern Siberia and their paleoseismic significance.- Sedim. Geol, 344, 5-19. doi: 10.1016/j.sedgeo.2016.02.014

MAGAŠ, N., MARINČIĆ, S. \& BENČEK, Đ. (1972): Tumač OGK 1:100.000 list Ploče K 33-35 [Basic Geological Map of SFRY 1:100000, Geology of the Ploče sheet - in Croatian].- Geološki institut Beograd\& Geološki zavod Zagreb, Savezni geološki zavod, Beograd, $46 \mathrm{p}$.

MARINČIĆ, S., MAGAŠ, N. \& BENČEK, Đ. (1972): Osnovna geološka karta SFRJ 1:100.00 list Ploče K 33-35 [Basic Geological Map of SFRY 1:100000, Ploče sheet - in Croatian].- Geološki institut Beograd \& Geološki zavod Zagreb, Savezni geološki zavod, Beograd.

MORELLÓN, M., ANSELMETTI, F.S., VALERO-GARCÉS, B., GIRALT, S., ARIZTEGUI, D., SÁEZG, A., MATA, M.P., BARREIRO-LOSTRES, F., RICO, M. \& MORENO, A. (2014): The influence of subaquatic springs in lacustrine sedimentation: Origin and paleoenvironmental significance of homogenites in karstic Lake Banyoles (NE Spain).- Sedim. Geol, 311, 96-111. doi: 10.1016/j.sedgeo.2014.07.004

MULDER, T. \& SYVITSKI, J.P.M. (1995): Turbidity currents generated at river mouths during exceptional discharges to the world oceans.- Journal of Geology, 103/3, 285-299. doi: 10.1086/629747

MUNSELL SOIL COLOR BOOK (2013): Munsell Soil Color Charts with genuine Munsell color chips.- Macbeth Division of Kollmorgem Instruments Corporation, New Windsor.

NOBLE, P.J., BALL, G.I., SMITH, S.B. \& ZIMMERMAN, S.H. (2015): Holocene paleoclimate potential of fallen Leaf Lake sediment cores, Tahoe Basin, California, USA.- Quaternary International, 387, 141. doi: 10.1016/j.quaint.2015.01.158

PEŁECHATY, M., PUKACZ, A., APOLINARSKA, K., PEŁECHATA, A. \& SIEPAK, M. (2013): The significance of Chara vegetation in the precipitation of lacustrine calcium carbonate.- Sedimentology, 60/4, 1017-1035. doi: 10.1111/sed.12020.

PENTECOST, A. (1984): The growth of Chara globularis and its relationship to calcium carbonate deposition in Malham Tarn.- Field Studies, 6/1, 53-58.

PETTIJOHN, F.J. (1975): Sedimentary Rocks (Third Edition).- Harper \& Row, Publishers, Inc., $628 \mathrm{p}$.

PILAAR BIRCH, S.E. \& VANDER LINDEN, M. (2018): A long hard road... Reviewing the evidence for environmental change and population history in the eastern Adriatic and western Balkans during the Late Pleistocene and Early Holocene.- Quat. Int., 465/B, 177-191. doi: 10.1016/j.quaint.2016.12.035

PLATT, N. \& WRIGHT, V.P. (1991): Lacustrine carbonates: facies models, facies distributions and hydrocarbons aspects.- In: ANADON, P., CABRERA, L.I. \& KELTS, K. (eds.): Lacustrine Facies Analysis, Spec. Publ. Int. Assoc. Sedimentol., 13, 57-74. doi: $10.1002 / 9781444303919 . c h 3$

PLENIČAR, M. (1954): Prispevek h geologiji Cerkniškega polja.- Proteus, XVII, 111-119.

POTTER, P.E. \& PETTIJOHN, F.J. (1977): Paleocurrents and basin analysis.- SpringerVerlag, Berlin, 550 p. doi: 10.1007/978-3-642-61887-1

READING, H.G. (1996): Sedimentary environments. Processes, Facies and Stratigraphy.Blackwell Science Ltd., Oxford, $628 \mathrm{p}$

REINECK, I.B. \& SINGH, I.B. (2012): Depositional Sedimentary Environments: With Reference to Terrigenous Clastics.- Springer Science \& Business Media, 439 p.

RETALLACK, G.J. (2001): Soils of the Past. An Introduction to Paleopedology.- Blackwell Science Ltd., Oxford, 404 p.

REY, J., MARTÍNEZ, J., MEDIAVILLA, R., SANTISTEBAN, J.I., CASTAÑO, S. \& DE LA LOSA, A. (2017): Geophysical characterization of stratigraphical surfaces: Basin floor and sedimentological architectural elements of Las Tablas de Daimiel (Quaternary of southern-central Spain).- Journal of Applied Geophysics, 136, 387-399. doi: 10.1016/j.jappgeo.2016.11.020

ROMEY, C., ROCHETTE, P., VELLA, C., ARFIB, B., ANDRIEU-PONEL, V., BRAUCHER, R., CHAMPOLLION, C., DOUCHET, M., DUSSOUILLEZ, P., HERMITTE, D., MATTIOLI, E., PARISOT, J.-C. \& SCHWENNINGER, J.-L. (2014): Geophysical and geomorphological investigations of a Quaternary karstic paleolake and its underground marine connection in Cassis (Bestouan, Cassis, SE France).Geomorphology, 214, 402-415. doi: 10.1016/j.geomorph.2014.02.021

ROMIĆ, M., BRAGATO, G., ZOVKO, M., ROMIĆ, D., MOSETTI, D., GALOVIĆ, L. \& BAKIĆ, H. (2014): The characteristics of soils developed from coastal paleosand (Korčula Island, Croatia).-Catena, 113, 281-291. doi: 10.1016/j.catena.2013.08.009 
RUDERSDORF, A., HARTMANN, K., YU, K., STAUCH, G. \& REICHERTER, K. (2015): Seismites as indicators for Holocene seismicity in the northeastern Ejina Basin, Inner Mongolia.- In: LANDGRAF, A., KÜBLER, S., HINTERSBERGER, E. \& STEIN, S. (eds.): Fault Rupture and Earthquake Hazards in Slowly Deforming Regions. Geological Society, London, Special Publications, 432 p., 213-231. doi: $10.1144 /$ SP432.6

SCHEIDEGGER, A.E. (1965): A theory of varve formation.- International Association of Scientific Hydrology, 10/1, 68-73. doi: 10.1080/02626666509493374

SMREKAR, A.A. (2000): Cerkniško polje kot primer poseljenega kraškega ranljivega območja.- Geographica Slovenica, 33/1, 117-156.

SOULIE-MARSCHE, I., BIEDA, S., LAFOND, R., MALEY, J., BAITOUDJI, M., VINCENT, P.M. \& FAURE, H. (2010): Charophytes as bio-indicators for lake level high stand at "Trou au Natron", Tibesti, Chad, during the Late Pleistocene.- Global Planet. Change, 72, 334-340

SOULIE-MARSCHE, I. \& GARCIA, A. (2015): Gyrogonites and oospores, complementary viewpoints to improve the study of the charophytes (Charales).- Aquatic Botany, 120, 7-17. doi:10.1016/j.aquabot.2014.06.003.

SHANMUGAM, G. (2017): Global case studies of soft-sediment deformation structures (SSDS): Definitions, classifications, advances, origins, and problems.- Journal of Palaeogeography, 6/4, 251-320. doi: 10.1016/j.jop.2017.06.004

SONDI, I. \& JURAČIĆ, M. (2010): Whiting events and the formation of aragonite in Mediterranean karstic marine lakes: New evidence on its biologically induced inorganic origin.- Sedimentology, 57, 85-95. doi: 10.1111/j.1365-3091.2009.01090.x

SURIĆ, M. \& JURAČIĆ, M. (2010): Late Pleistocene - Holocene environmental changes - records from submerged speleothems along the Eastern Adriatic coast (Croatia).- Geol. Croat., 63/2, 155-169. doi: 104154/gc.2010.13

ŞIMŞEK, F. B. \& ÇAĞATAY, M.N. (in press): Late Holocene high resolution multi-proxy climate and environmental records from Lake Van, eastern Turkey.- Quat. Int.

TERZIĆ, J., ŠUMANOVAC, F. \& BULJAN, R. (2007): An assessment of hydrogeological parameters on the karstic island of Dugi Otok, Croatia.- Journal of Hydrology, 343/1-2, 29-42. doi: 10.1016/j.jhydrol.2007.06.008

TOMASOVIĆ, M., PERKIĆ, D. \& ALDUK, I. (2008): Topografija stećaka u Hrvatskoj.In: TOMASOVIĆ, M. (ed.): Stećci, katalog izložbe, Galerija Klovićevi dvori, Zagreb, $293 \mathrm{p}$.
TRAPOTE, M.C., VEGAS-VILARRÚBIA, T., LÓPEZ, P., PUCHE, E., GOMÀ, J., BUCHACA, T., CAÑELLAS-BOLTÀ, N., SAFONT, E., CORELLA, J.P. \& RULL, V. (2018): Modern sedimentary analogues and integrated monitoring to understand varve formation in the Mediterranean Lake Montcortès (Central Pyrenees, Spain).Palaeogeogr. Palaeoclimatol. Palaeoecol., 496, 292-304. doi: 10.1016/j.palaeo.2018.01.046

TUCKER, M.E. (2008): Sedimentary Petrology - An Introduction To The Origin Of Sedimentary Rocks 3Rd Edition.- Wiley Blackwell, $261 \mathrm{p}$.

TUCKER, M.E. \& WRIGHT, V.P. (1990): Carbonate Sedimentology.-Blackwell Science, Oxford, 482 p. doi: 10.1002/9781444314175

VAN LOON, A.J. \& BRODZIKOWSKI, K. (1987): Problems and progress in the research on soft-sediment deformations.- Sedim. Geol., 50/1-3, 167-193. doi: 10.1016/00370738(87)90032-7

VLAHOVIĆ, I., TIŠLJAR, J., VELIĆ, I. \& MATIČEC, D. (2002): The Karst Dinarides are Composed of Relics of a Single Mesozoic Platform: Facts and Consequences.Geol. Croat., 55/2, 171-183.

VALVASOR, J. W. (1689): Die Ehre dess Hertzogthums Crain.- Laybach. I. Theil, 696 p. VRABEC, M. (1994): Some thoughts on the pull-apart origin of karst poljes along the Idrija strike-slip fault zone in Slovenia.- Acta Carsologica, 23, 158-168.

WALKER, M.J.C., BERKELHAMMER, M., BJÖRCK, S., CWYNAR, L.C., FISHER, D.A., LONG, A.J., LOWE, J.J., NEWNHAM, R.M., RASMUSSEN, S.O. \& WEISS, H. (2012): Formal subdivision of the Holocene Series/Epoch: a Discussion Paper by a Working Group of INTIMATE (Integration of ice-core, marine and terrestrial records) and the Subcommission on Quaternary Stratigraphy (International Commission on Stratigraphy).- Journal of Quaternary Science, 27/7, 649-659. doi:10.1002/jqs. 2565

WEEKS, A.M., DE JAGER, N.R., HARO, R.J. \& SANDLAND, G.J. (2017): Spatial and Temporal Relationships Between the Invasive Snail Bithynia tentaculata and Submersed Aquatic Vegetation in Pool 8 of the Upper Mississippi River-- River Res. Applic., 33, 729-739. doi:10.1002/rra.3123

ZOLITSCHKA, B. (2013): Varved lake sediments.- In: ELIAS, S.A. (ed.): Encyclopedia of Quaternary Science (Second Edition), Elsevier, Amsterdam, 573-581. doi: 10.1016/B978-0-444-53643-3.00056-X

ZOLITSCHKA, B., FRANCUS, P., OJALA, A.E.K. \& SCHIMMELMANN, A. (2015): Varves in lake sediments - a review.- Quat. Sci. Rev., 117, 1-41. doi: 10.1016/j. quascirev.2015.03.019 